\title{
Attitudes and Approaches of Finnish Retrofit Industry Stakeholders toward Achieving Nearly Zero-Energy Buildings
}

\author{
Sadaf Alam ${ }^{1,2, *}$, Miimu Airaksinen ${ }^{3}$ and Risto Lahdelma ${ }^{1,4}$ (D) \\ 1 Department of Mechanical Engineering, School of Engineering, Aalto University, 02150 Espoo, Finland; \\ risto.lahdelma@aalto.fi \\ 2 Department of Built Environment, School of Engineering, Aalto University, 02150 Espoo, Finland \\ 3 Finnish Association of Civil Engineers RIL, 00100 Helsinki, Finland; miimu.airaksinen@ril.fi \\ 4 Department of Mathematics and Systems Analysis, School of Science, Aalto University, 02150 Espoo, Finland \\ * Correspondence: sadaf.alam@aalto.fi
}

check for

updates

Citation: Alam, S.; Airaksinen, M.;

Lahdelma, R. Attitudes and

Approaches of Finnish Retrofit

Industry Stakeholders toward

Achieving Nearly Zero-Energy

Buildings. Sustainability 2021, 13,

7359. https://doi.org/10.3390/

su13137359

Academic Editors: Muhammad Asif and Tomonobu Senjyu

Received: 7 May 2021

Accepted: 17 June 2021

Published: 30 June 2021

Publisher's Note: MDPI stays neutral with regard to jurisdictional claims in published maps and institutional affiliations.

Copyright: (C) 2021 by the authors. Licensee MDPI, Basel, Switzerland. This article is an open access article distributed under the terms and conditions of the Creative Commons Attribution (CC BY) license (https:/ / creativecommons.org/licenses/by/ $4.0 /)$.

\begin{abstract}
Key stakeholders in industry are highly responsible for achieving energy performance targets. Particularly, this paper assesses the attitudes, approaches, and experiences of Finnish construction professionals regarding energy-efficient buildings, or nZEBs. A three-tier investigation was conducted including surveys and expert interviews with several stakeholders. The structure of this approach was informed by preliminary data and information available on the Finnish construction sector. The questionnaire showed that the stakeholders ranked energy efficiency and embodied energy/carbon as very important. The survey highlighted that the importance of the embodied carbon $\mathrm{CO}_{2}$ in the materials is less important than the energy efficiency from many of the stakeholders' points of view. "Energy efficiency" is very important for ESCOs, contractors, and facility managers followed by architects, HVAC engineers, and construction design engineers. Nevertheless, the opinions of architects ranked "embodied energy $\mathrm{CO}_{2}$ " as the most important regarding nZEB. When it comes to the importance of "running time emissions" toward nZEB, contractors and ESCO companies ranked it as 1 for importance followed by property owners (78\%) and tenants (75\%). It is very fascinating to see from the survey that "running time carbon emissions" has been ranked 1 (very important) by all stakeholders. This study will enable construction industry stakeholders to make provisions for overcoming the barriers, gaps, and challenges identified in the practices of the nZEB projects. It will also inform the formulation of policies that drive retrofit uptake.
\end{abstract}

Keywords: nearly zero energy buildings; economic feasibility; energy efficiency; social acceptability; stakeholders; sustainable development goals

\section{Introduction}

Building stock is one of the major contributors to greenhouse gasses [1,2]. The EU has set an aggressive goal to increase the number of 'nearly zero energy buildings' (nZEBs) by 2020, which now appears to be an unfulfilled target. By 2030, the 2030 Climate and Energy Ambition of the European Union (EU) set a target of 55\% emissions reduction compared with 1990 [3].

The new 'Finland National Strategy' [4] also aims to raise the number of nZEBs but does not provide detailed specifications. However, concepts of nearly zero-energy building and associated specifications are continuing. Variations in building environment and culture throughout Europe make it somewhat challenging for the European Building legislation (EPBD) to administer a standardized solution to nZEBs [5,6]. In many countries, the building stock contributes to more than $40 \%$ of the total amount of greenhouse gas emissions [7].

Finland accounts for $41.2 \%$ of the overall electricity demand from clean energy sources, which is near the top of the European Union (EU) the Member States. Finland plans to increase its share of renewable energy to $50 \%$ by 2030 , making Finland one of the EU 
frontrunners in renewable energy [8]. The terms 'ZEBs (zero energy buildings)' and 'NZEBs (net-zero energy buildings)' have both been adopted by different researchers. Detailed definitions and descriptions can be found by Marszal et al. [9] and Sartori et al. [10].

\section{nZEB Definitions}

The EU strategy policy framework focused on reducing energy use while obtaining significant building savings. Among the various policies action is the Energy Performance of Building Directive recast (EPBD recast, Directive 2010/31/EC) [11]. The energy quality directive (EED) (EU, 2012/27/EU) and the Green Energy Directive (RED) (EU, 2009/28/EU) are additional directives aimed at improving energy production in buildings [12]. As per EPBD recast by 31 December 2018, all-new buildings must become nZEBs, and by 31 December 2018, new buildings occupied by public authorities must become nZEBs as well [13].

An nZEB is defined as a building with very high energy performance, as determined by Annex I. Member states have been stated by EPBD to detail NZEB definitions reflecting national, regional, or local conditions, and a numerical indicator of primary energy use expressed in $\mathrm{kWh} / \mathrm{m}^{2}$ per year. The primary energy factors used in the measurement of primary energy usage should be based on the appropriate European standard and the national or annual average.

Member states will provide the quantitate definition of "very high energy performance" and a very significant extent by energy from renewable sources. In addition, each government can specify the definition of "nearby" and category of primary energy to be used in numerical performance metrics.

In addition, several researchers [14] have defined and given some dominant terms for defining ZEB, which is illustrated in Table 1.

Table 1. Dominant terms used to define ZEB.

\begin{tabular}{|c|c|c|}
\hline S.no. & Dominant Terms & Definition \\
\hline 1 & Net-zero site energy use & $\begin{array}{l}\text { It produces at least as much energy as it uses in a year when accounted for at } \\
\text { the site. }\end{array}$ \\
\hline 2 & Net-zero source energy * use & $\begin{array}{l}\text { It produces at least as much energy as it uses in a year when accounted for at } \\
\text { the source. }\end{array}$ \\
\hline 3 & Net-zero energy emissions & $\begin{array}{l}\text { It produces at least as much emissions-free renewable energy as it uses it from } \\
\text { emissions producing energy sources. }\end{array}$ \\
\hline 4 & Net-zero cost & $\begin{array}{l}\text { It balances the cost that the utility pays the building owner for the energy } \\
\text { exports of the building to the grid with the cost that the owner pays the utility } \\
\text { for the energy consumed and the energy services per year. }\end{array}$ \\
\hline 5 & Energy Plus & $\begin{array}{l}\text { It produces more energy from onsite renewable energy sources than the energy } \\
\text { it consumes from the grid. It also incorporates a combination of small-scale } \\
\text { power generators and low-energy building solutions such as passive solar } \\
\text { building design and super insulation design. }\end{array}$ \\
\hline
\end{tabular}

* Source energy: It refers to the primary energy used to generate and deliver the energy to the site.

Furthermore, the implementation of cost optimality is another EPBD revision. In Delegated Regulation, No. 244/2012 supplementing the EPBD recast [15], a framework of comparative methodology to work out cost-optimal levels of minimum energy performance requirement for buildings and its element has been given. The meaning of the cost-optimal level is the energy performance level which leads to the lowest cost during the estimated life cycle.

The method includes, first, identifying benchmarks and the use of energy-efficient initiatives to minimize primary energy consumption and explore the selection of the most economically productive solution [16-18]. Several experiments illustrate how a diverse scenario of building and climate types describes Europe [19,20]. Therefore, different costoptimal levels and bundles of energy-efficient measures can be found [21]. 
The cost-optimal concept is closely associated with the nZEBs as defining cost optimality and minimal commitment for the renovation of buildings and new buildings.

The European Commission Recommendation on guidelines for the promotion of nZEBs [22] states that the nZEBs cannot have the same level of performance throughout Europe.

Flexibility is required in terms of the effect of climate conditions on heating and cooling demands and energy efficiency and on renewable energy packages. In comparison to the EPBD principle of the nZEB, new buildings on the market seem to qualify according to separate terms and definitions.

However, despite the widespread discussion over the past ten years, there has been no general common consensus on the technical importance of these terms. The current condition for the development of the applied national nZEB descriptions has improved in Europe relative to the previous reports [23]. Ref [23] reports a qualitative evaluation of the Current status of nZEBs development in the Member States. However, only a few Member States have generated policies for stimulating cost-effective nZEB renovation [24].

The building owners and consumers represent the most critical stakeholders, when it comes to assessing the share of energy efficiency and renewable energy technologies (RET) opportunities for buildings as renovations happen at their expense [25].

A study on the acceptability of nZEB renovation strategies in Norway, ref. [26] found that the choice of the homeowner's renovation preference could be affected by social and economic variables, such as an initial expense, repayment periods, and return on investments.

The findings will promote the development and deployment of RETs for residential buildings, including nZEBs, in the urban areas of Finland, and encourage policymakers, technology suppliers, energy and buildings stakeholders, and building engineers.

This study will enable construction industry stakeholders to make provisions for overcoming the barriers, gaps, and challenges identified in the practices of the retrofit projects. It will also inform the formulation of policies that drive retrofit uptake.

\section{Literature Review}

\subsection{Stakeholders Attitudes toward nZEB}

Stakeholders have a significant impact on the progress of projects, particularly in the case involving complex projects with heterogeneous stakeholders, so their experience is indeed important for project management and delivery. The management of stakeholders is crucial for the performance of projects, especially in the case of a complex project [27]. Stakeholders can be described as a person or group of persons influenced by or able to influence a project [28]. For project success, strong collaboration among stakeholders is important as a project can be viewed as a temporary organization for stakeholders pursuing a goal together [29]. McElroy and Mills [30] have stated that the objective of stakeholder management is to achieve project success by continually developing their relationships.

Therefore, it is a significant and crucial issue of stakeholder management to see how stakeholders influence the success of projects.

There are six major stakeholders in existing research: namely, the owner, designer, contractor, supplier, occupant, energy manager and government, whose activities will directly or indirectly affect building energy consumption, such as the owner's and designer's decisions, contractor's construction, and the energy manager's and occupant's behavior [31].

\section{Building Life Cycle and Key Stakeholders}

Table 2 lists the role of the diverse stakeholders and their main concerns throughout the building lifecycle phase. 
Table 2. Role of the key stakeholders and their concerns in the building life cycle (adapted from [32]).

\begin{tabular}{|c|c|c|c|c|c|c|c|}
\hline Key Stakeholder & Investors & Manufacturer/Supplier & $\begin{array}{c}\text { Banks/Financial } \\
\text { Institutions }\end{array}$ & Contractors & Planners/Designers & End User/Owner & Public Authorities \\
\hline Lifecycle Phases & $\begin{array}{l}\text { Project development } \\
\text { phase/concept/design } \\
\text { phase }\end{array}$ & $\begin{array}{c}\text { Construction } \\
\text { phase/revitalization } \\
\text { phase/modernization } \\
\text { phase/deconstruction } \\
\text { phase }\end{array}$ & $\begin{array}{l}\text { Project development } \\
\text { phase/idea/capital }\end{array}$ & $\begin{array}{c}\text { Construction } \\
\text { phase/revitalization } \\
\text { phase/modernization } \\
\text { phase/ } \\
\text { deconstruction phase }\end{array}$ & $\begin{array}{l}\text { Project development } \\
\text { phase/ } \\
\text { concept/design phase/ } \\
\text { construction phase }\end{array}$ & $\begin{array}{c}\text { Operation } \\
\text { phase/maintenance } \\
\text { phase }\end{array}$ & All phases \\
\hline Main Concerns & $\begin{array}{l}\text { Return of investment; } \\
\text { economic feasibility; } \\
\text { corporate social } \\
\text { responsibility; } \\
\text { regulation; } \\
\text { personal beliefs; } \\
\text { company image }\end{array}$ & $\begin{array}{c}\text { Energy supply; } \\
\text { availability of natural } \\
\text { resources; } \\
\text { economic feasibility; } \\
\text { cost-efficiency; } \\
\text { workforce; corporate } \\
\text { social responsibility; } \\
\text { regulation; personal } \\
\text { beliefs; company image }\end{array}$ & $\begin{array}{l}\text { Return of investment; } \\
\text { company image }\end{array}$ & $\begin{array}{c}\text { Materials and energy } \\
\text { supply; economic } \\
\text { feasibility; cost-efficiency; } \\
\text { workforce; } \\
\text { corporate social } \\
\text { responsibility; regulation; } \\
\text { personal beliefs; company } \\
\text { image }\end{array}$ & $\begin{array}{c}\text { Knowledge; creative } \\
\text { and efficient application } \\
\text { of } \\
\text { technologies; } \\
\text { cost-efficiency; } \\
\text { corporate } \\
\text { social responsibility; } \\
\text { regulation; personal } \\
\text { beliefs; company image }\end{array}$ & $\begin{array}{l}\text { Well-being; economic } \\
\text { feasibility; lifestyle; } \\
\text { personal beliefs; } \\
\text { company image }\end{array}$ & $\begin{array}{l}\text { Regulations and control; } \\
\text { well-being }\end{array}$ \\
\hline
\end{tabular}




\subsection{Role of the Stakeholders in the Construction Industry}

In all construction projects, numerous stakeholders are involved at each stage directly or indirectly. An integrated design process (IDP) involves all participants in the early design phase of the project. This indicates that all parties work together in the preliminary design process, from setting the project priorities to identifying measurable design criteria for these objectives.

The different stakeholders of the early design stage have been divided into three main groups (refer to Figure 1). These groups are as follows: (a) society and citizens: local authorities, citizens; (b) clients and users: end-users, investors, initiators, developers, building owners, facility managers, and (c) construction sector: builders, designers, suppliers [33]. Traditionally, the most powerful stakeholders have been (a) local authorities through the building regulations and $(\mathrm{b})$ investors who have been obsessed with the cost of project capital and therefore have neglected potential gains by a lowered life cycle cost.
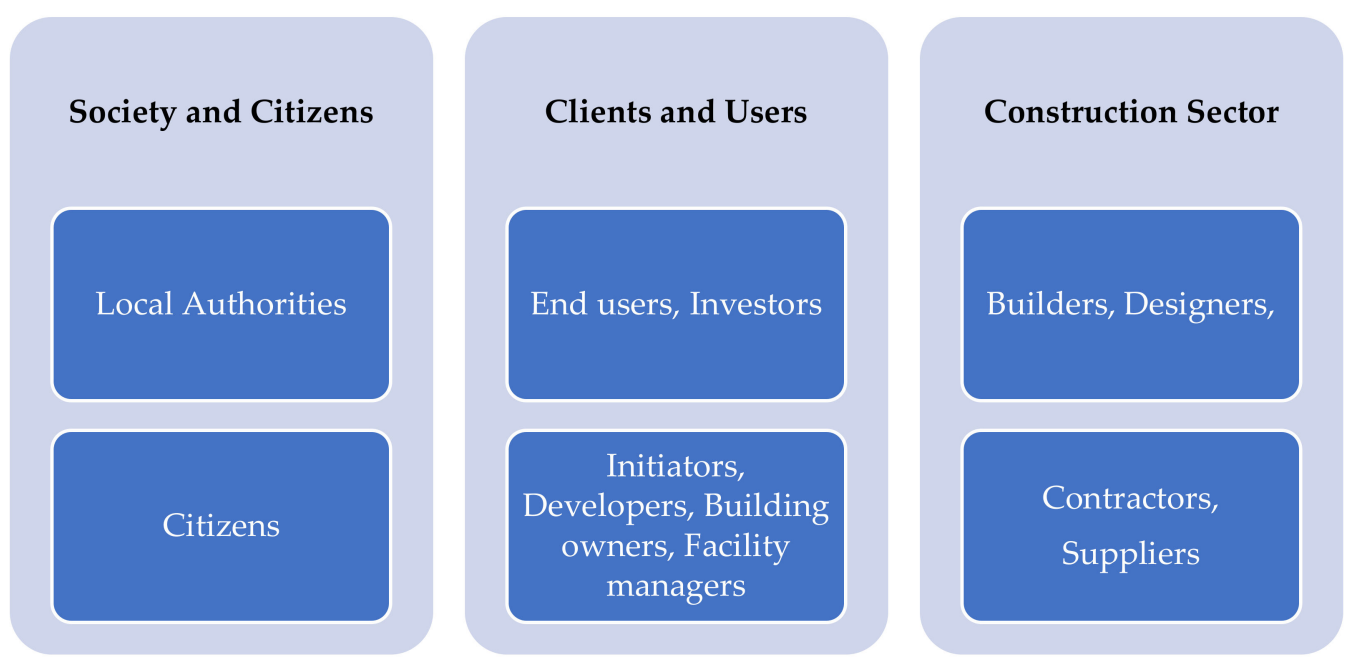

Figure 1. Three main groups of stakeholders.

If the environmental value of the life cycle is considered, all stakeholders are acknowledged and motivated to cooperate, collaborate, and influence each other's projects.

Each stakeholder introduces their expertise and personal agenda to the design process, and the result is a more informed and balanced design.

The building owners are obsessed with maintenance costs and favor decreased energy usage during the building life.

Facility managers usually struggle with practical issues, including the cleaning of façades and the maintenance of facilities. They are directly responsible for the actual everyday performance of the building, and their contribution to the design process is invaluable.

Building users must be satisfied with the facilities and comfort level provided. Failing to provide the needs of the user may lead to wasteful post-occupancy alterations to the building design and decreased building value.

Building services engineers are concerned with the building geometry and material properties, which are traditionally fixed after the planning stage. Reduced levels of energy consumption can be achieved when architects and engineers design the building shape in parallel. The building orientation may be changed, or external shading may be added to reduce solar gain and save on cooling energy. Glazing size and properties may be optimized to maximize daylighting or to reduce annual heating and cooling loads.

Environmental impact consultants may wish to comment on the suitability of the project site to reduce the development of unsuitable sites due to biodiversity and ecological concerns, to reduce light pollution, and to reduce the transport-related carbon footprint of the building. 
Contractors may provide comments on the buildability of the building design and may propose practical measures to simplify the building process, thus saving energy and materials.

Material suppliers can inform the design team regarding the embodied energy of materials. Then, material options can be categorized and selected based on where the material will be sourced from and how it will be processed before arriving at the site. An integrated design process can achieve improved building performance with lower costs and fewer disruptive changes during the later project stages.

\subsection{Retrofit Industry and Construction Professionals}

Finland's Integrated Energy and Climate Plan contains the national targets and the related policy measures to achieve the EU's energy and climate targets. Concerning energy efficiency, following the EED, Finland's indicative national energy efficiency target for 2020 is the absolute level of final energy consumption at $310 \mathrm{TWh}$. The energy efficiency target to contribute to the EU 2030 target in final energy consumption is 290 TWh. In 2017, Finland had achieved a level of 294 TWh for final energy consumption, corresponding to 371 TWh of primary energy consumption.

Market development, adaptability, and filling the gaps in homeowner information are of vital importance and are governed by the growing construction industry. The provision of incentives supports the market penetration of nZEBs, and a recent market report on Energy Service Companies (ESCOs) in Europe notes that the Irish retrofit industry is growing rapidly due to such incentives [34]. The retrofit industry is an important stakeholder for nZEB, and key actors include professionals such as architects, engineers, small and medium businesses, contractors, and other construction professionals.

For highly efficient buildings, the value supply chain of designers, architects, construction workers, clients, and policymakers needs to be integrated with the current demand for quality and precision.

In the Irish context, conventional construction professions, such as carpenters, electricians, and manufacturers, directly interact with the owners, and it is important to establish the supply chain in value [35]. The Build-up skills road map is a key component of the Build 2020 plan formed by a coalition of governmental departments, state agencies, training centers, and construction workers to enhance skills for tradesmen and retrofit professionals [20].

To address current technological, social, economic, and environmental hurdles, retrofitting companies need a greater agreement around processes, tools, and best practices, as discussed in this study. Coordinated engagement between industry stakeholders in the starting, production, and delivery of projects will improve the quality and technology necessary for retrofit [36]. Several studies have explored the criteria of end users to help retrofitting decision making using surveys [37,38].

Nevertheless, very few studies have assessed the demands for low energy building of building industry stakeholders in Europe [39]. They suggested that most countries need knowledge and training to encourage potential business growth.

They also suggested that the growth of ESCOs in Europe lacks confidence and reliable information. Established skills in the building industry are quite high, but they are not enough matched to the low energy building approach.

The ZEBRA 2020 project aims to develop mechanisms to track the market acceptance of nZEBs throughout Europe and its suggestions are anticipated [40]; however, it does not include Finland in its consortium.

Therefore, a thorough stakeholder consultation process has been initiated in this study to recognize the barriers, gaps, and challenges to the retrofit industry in Finland. This process, outlined in the following section of the paper, comprises a construction professional survey (Section 3.1) and in-depth interviews (Section 3.3). 


\subsection{Aims and Objectives}

When it comes to deep retrofitting, the engagement of the stakeholders plays a very vital role. The role of the key stakeholders in the industry becomes highly responsible for an informed understanding and decision making. To this end, this study aims to analyze the barriers and gaps toward nearly zero energy buildings by understanding the attitudes and approaches of the stakeholders.

\section{Research Design and Methods}

The aim of this investigation is to understand the attitudes and approaches adopted by retrofit industry professionals in their practices or businesses toward delivering or achieving nearly zero-energy buildings. To this end, a three-tier methodology was designed comprising of a literature review, surveys (60 respondents), and a series of in-depth interviews (4 participants).

\subsection{Aims and Objectives}

This study employs a methodology survey questionnaire that considers various user segment categories, the financial sector, and among sellers and policy makers at the local, national, and international level working on low-carbon buildings solutions.

Questions for the questionnaire are divided into 4 different categories: individual perspective, SDGs (Sustainable Development Goals) goal perspective, material's embodied carbon perspective, and market energy-efficiency perspective, as illustrated in Figure 2 below.

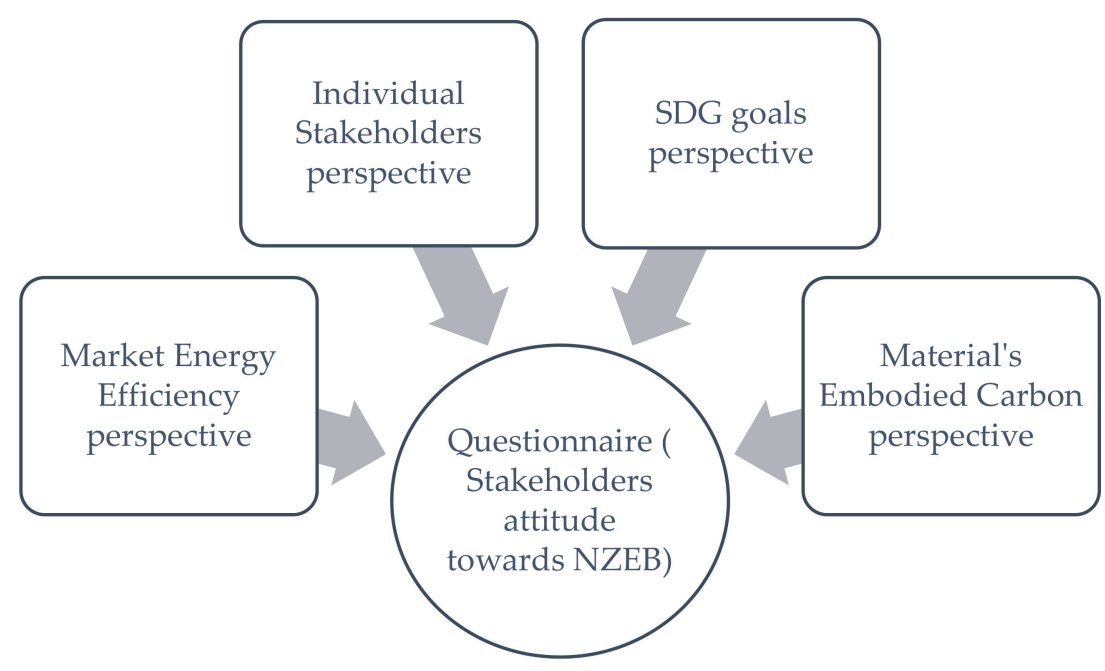

Figure 2. Questionnaire design methodology.

A semi-structured online questionnaire was compiled on webropol and distributed between May and August 2019 via email and public forum (in Supplementary Material). The survey was composed of qualitative/open-ended and quantitative questions based on multiple choice, rank order, Likert, and rating scales designed to capture the characteristics of individual retrofit businesses. Sixty detailed responses were received, giving a response rate of $15 \%$. A purposeful sampling technique was applied to select the respondents from within Finland [41].

\subsection{Aims and Objectives}

The questionnaire was published using an online survey system. The public version of the survey was launched on 27th July 2019. The questionnaire was linked to an internet panel management and survey distribution platform, which was applied to collect the required amount of responses through several internet panels. The platform narrowed 
the focus population to those residing in Finland and split the sample participants into six categories (18-24, 25-35, 36-46, 47-57,58-68 and 69-80).

These age groups were chosen specifically to understand the role of age condition on the views on NZEB buildings. The ratio of the interviewees for the above-mentioned information is shown in Figure 3.

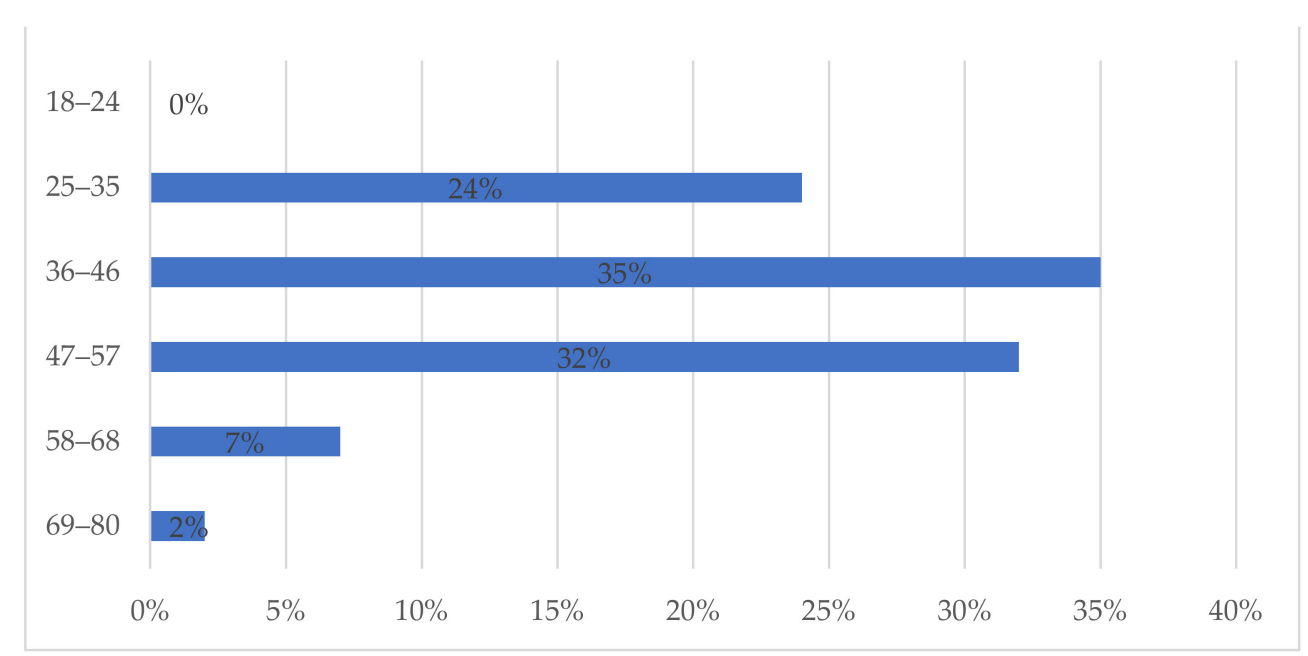

Figure 3. Percentage of the respondents by age.

Approximately $35 \%$ of the respondents were in the age range of $36-46$ followed by the age group of $47-57$ with $32 \%$. Most of the participants as stakeholders (Figure 4 ) were HVAC engineers $(16 \%)$, followed by the largest group of participants, construction design engineers $(15 \%)$ and property owners (15\%). The other largest groups were ESCOs $12 \%$, builders $(11 \%)$, architects $(10 \%)$, tenants, facility managers, and contractors with $7 \%$ each.

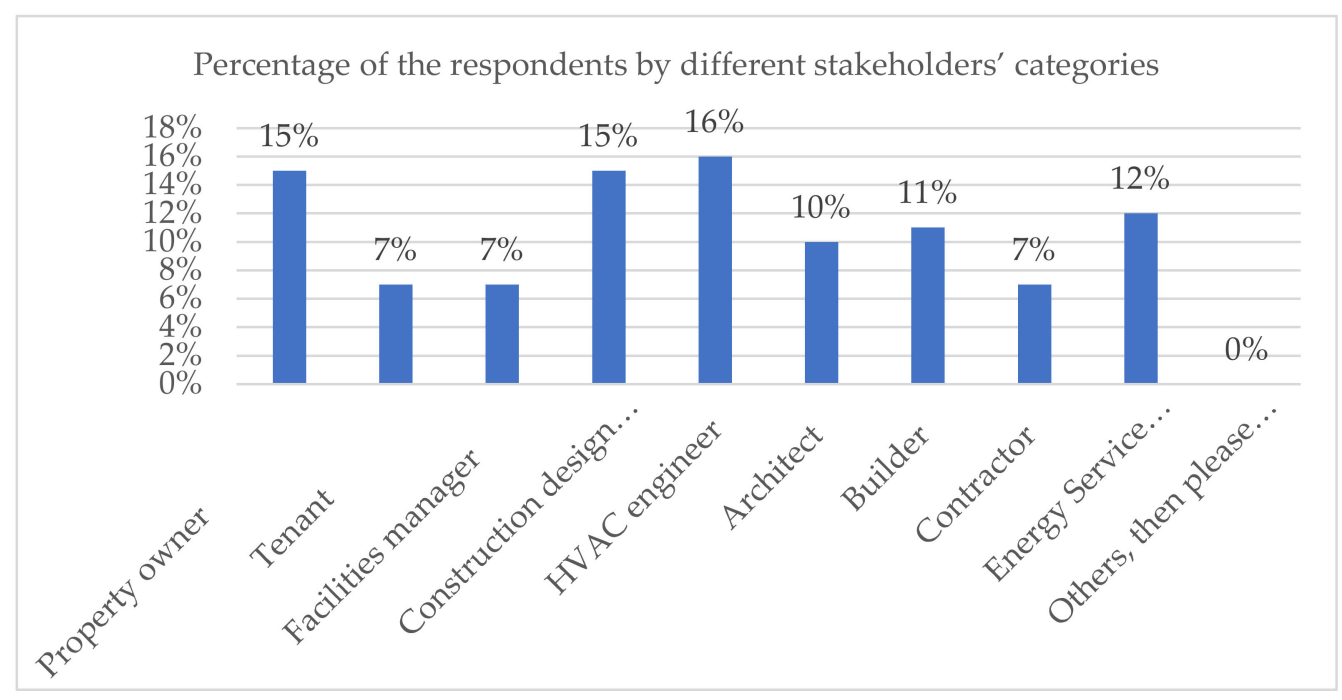

Figure 4. Percentage of the respondents by different stakeholders' categories.

\subsection{Data Analysis}

The collected data were exported from the Online Survey system to a spreadsheet for detailed review following the completion of our online survey. Two types of variables (independent and dependent variables) were selected according to our survey questions as follows.

(1) Independent variables in questions: Q1-Q8

(2) Dependent variables in questions: Q5-Q10 
The open questions were analyzed through a simple qualitative content analysis by identifying certain words and calculating their repetition for each question. Using the spreadsheet calculations, the data was analyzed, and the selection of the statistical characteristic of the data was identified using standard statistical operations. Various forms of statistical analysis, such as correlations, variables, and text mining analysis were used to analyze the data.

\subsection{Background Data}

As discussed, most of the respondents were in the age range of 36-46 years and mostly working in the existing buildings of Finland, as shown in the Figure 5. The difference is not so big; $47 \%$ and $53 \%$ are quite close.

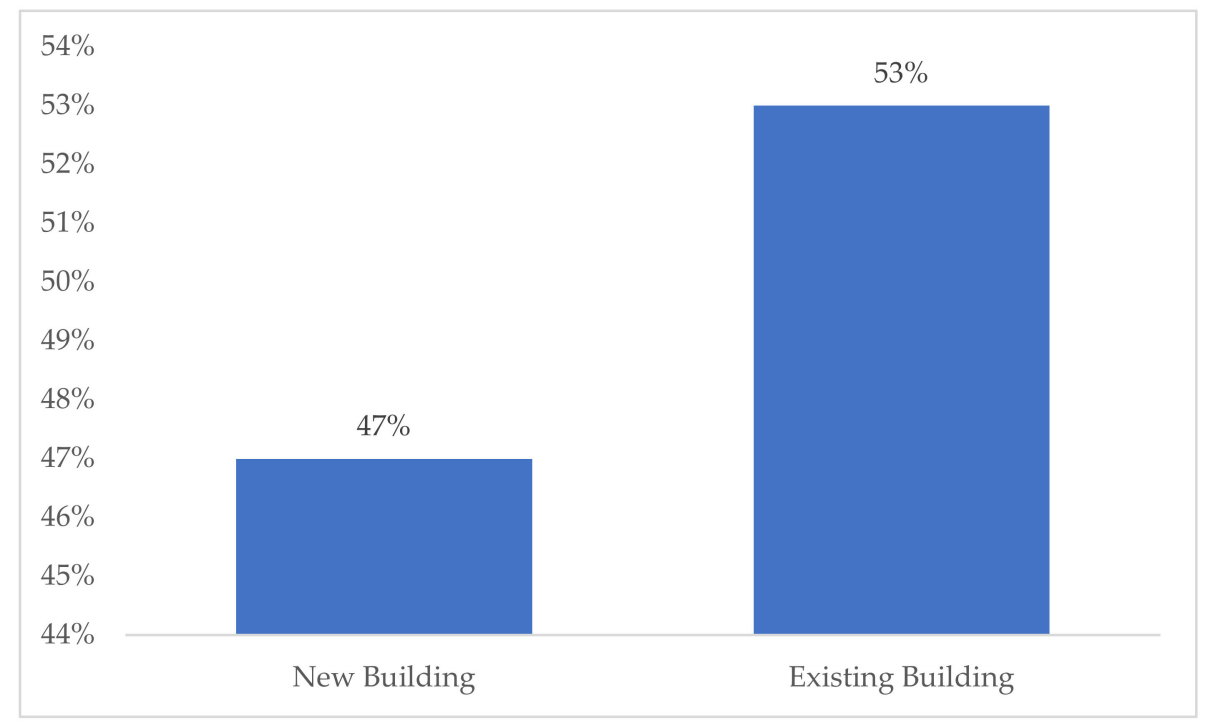

Figure 5. Building types where the stakeholders work.

Text mining analysis shows that most of the respondent's stakeholders $(60 \%)$ own office buildings followed by residential buildings with 55\%. Furthermore, Figure 6 below highlights the responses of Q4. Additionally, we used word mapping by hierarchical and clustering analysis to analyze the reason behind their living in such houses/apartments.

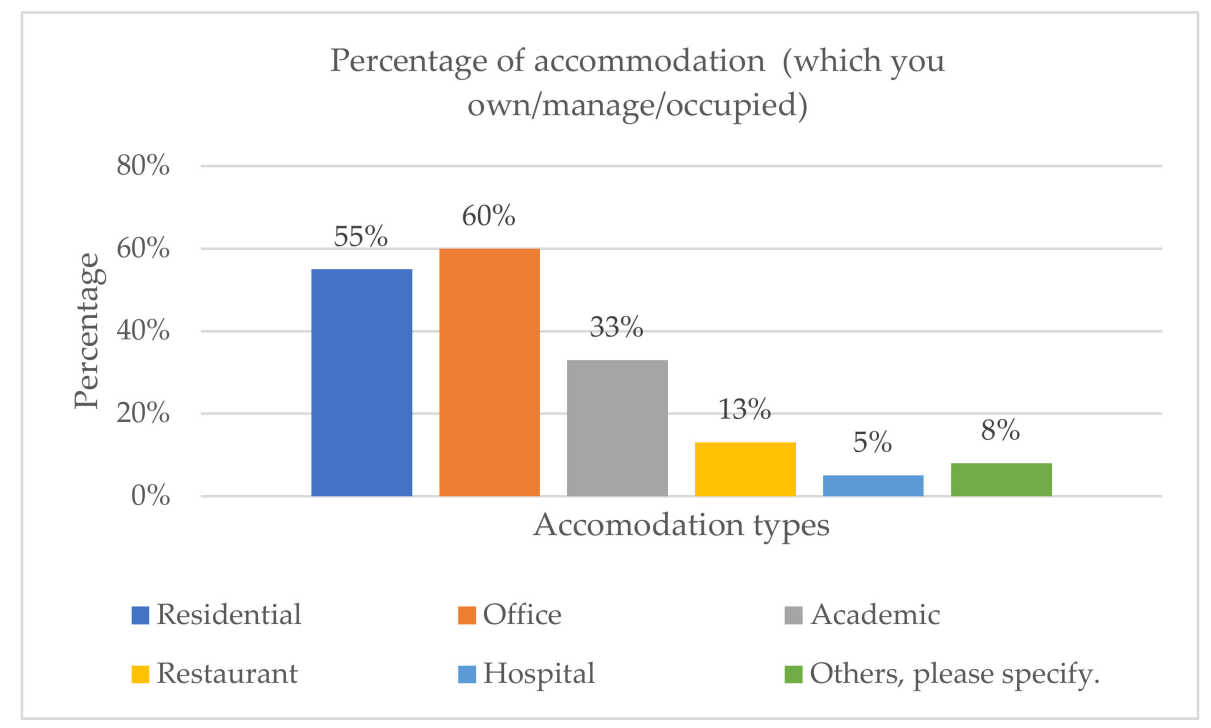

Figure 6. Building type (which you own/manage/occupy). 


\section{Results}

\subsection{Survey Results: Assessing the Stakeholder Perspective}

The results are summarized and discussed in the following three categories: (1) importance of energy efficiency and the focus on embodied energy $\mathrm{CO}_{2}$ in the materials, (2) usage of UN (United Nations) sustainable goals, and (3) expectations and needs.

4.1.1. Importance of Energy Efficiency and the Focus on Embodied Energy $\mathrm{CO}_{2}$ in the Materials

The survey highlights (refer Figure 7) the importance of energy efficiency and the embodied carbon $\mathrm{CO}_{2}$ in the materials among the stakeholders. Q7 of the survey produced statistical results with a median of 1.97 for "embodied carbon $\mathrm{CO}_{2}$ in the materials" and 1.27 for "energy efficiency", which shows that the importance of the embodied carbon $\mathrm{CO}_{2}$ in the materials is less important than the energy efficiency from the stakeholders' point of view.

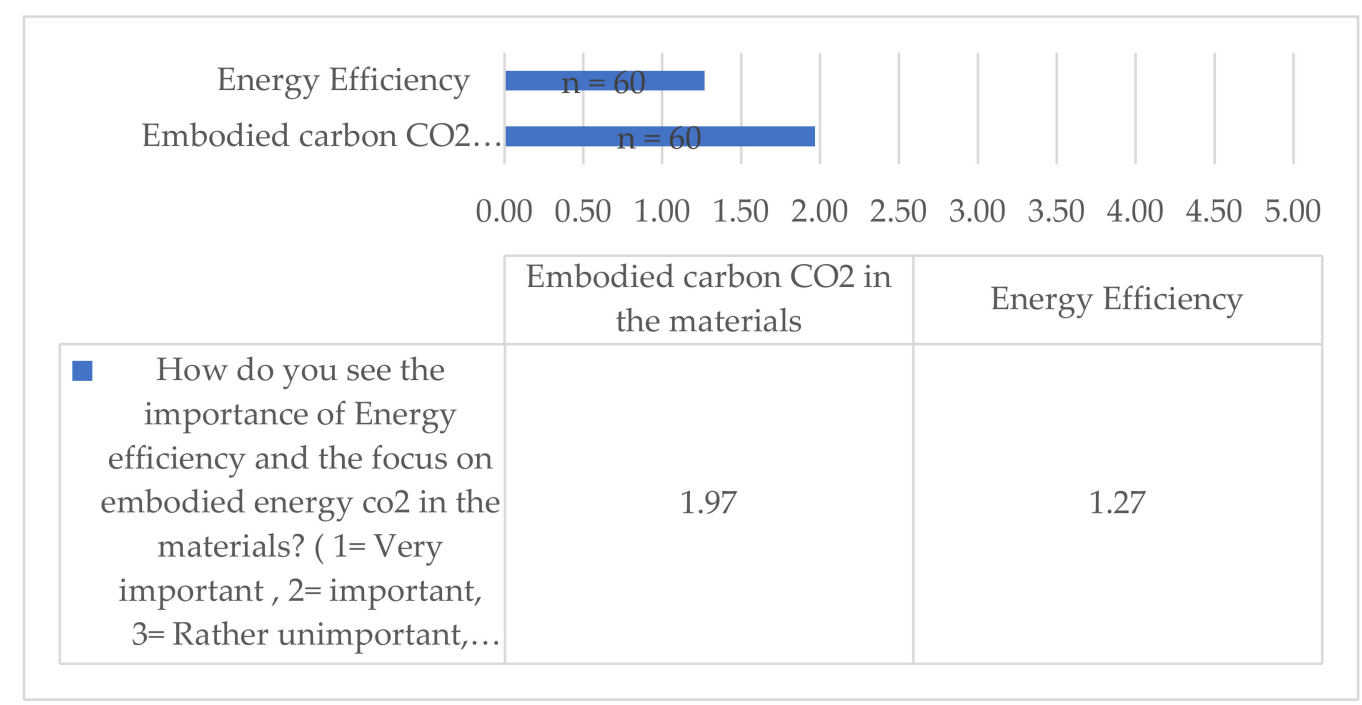

Figure 7. Respondents' (stakeholders') opinion about the importance of energy efficiency and embodied energy $\mathrm{CO}_{2}(\mathrm{Q} 7)$.

It can be seen from Figure 8 that tenants ranked the energy efficiency 2 (which is important) when it comes to the nearly zero energy building, following builders ( $12 \%)$, who ranked energy efficiency importance between 1 and 2 (somewhat important). Figure 8 also highlights that "energy efficiency" is very important for ESCOs, contractors, and facility managers followed by architects, HVAC engineers, and construction design engineers.

When it comes to the responses of the importance of "embodied energy $\mathrm{CO}_{2}$ " toward nearly zero energy buildings (refer to Figure 9), the survey results highlighted that for architects, embodied energy $\mathrm{CO}_{2}$ was ranked the most important.

Figure 10 further shows that $83.3 \%$ of architects ranked it as 1 (very important) and $16.7 \%$ of them ranked 2 (which is important). However, it seems for other stakeholders e.g., facility managers, tenants, property managers, and ESCOs, embodied carbon is rather unimportant. 


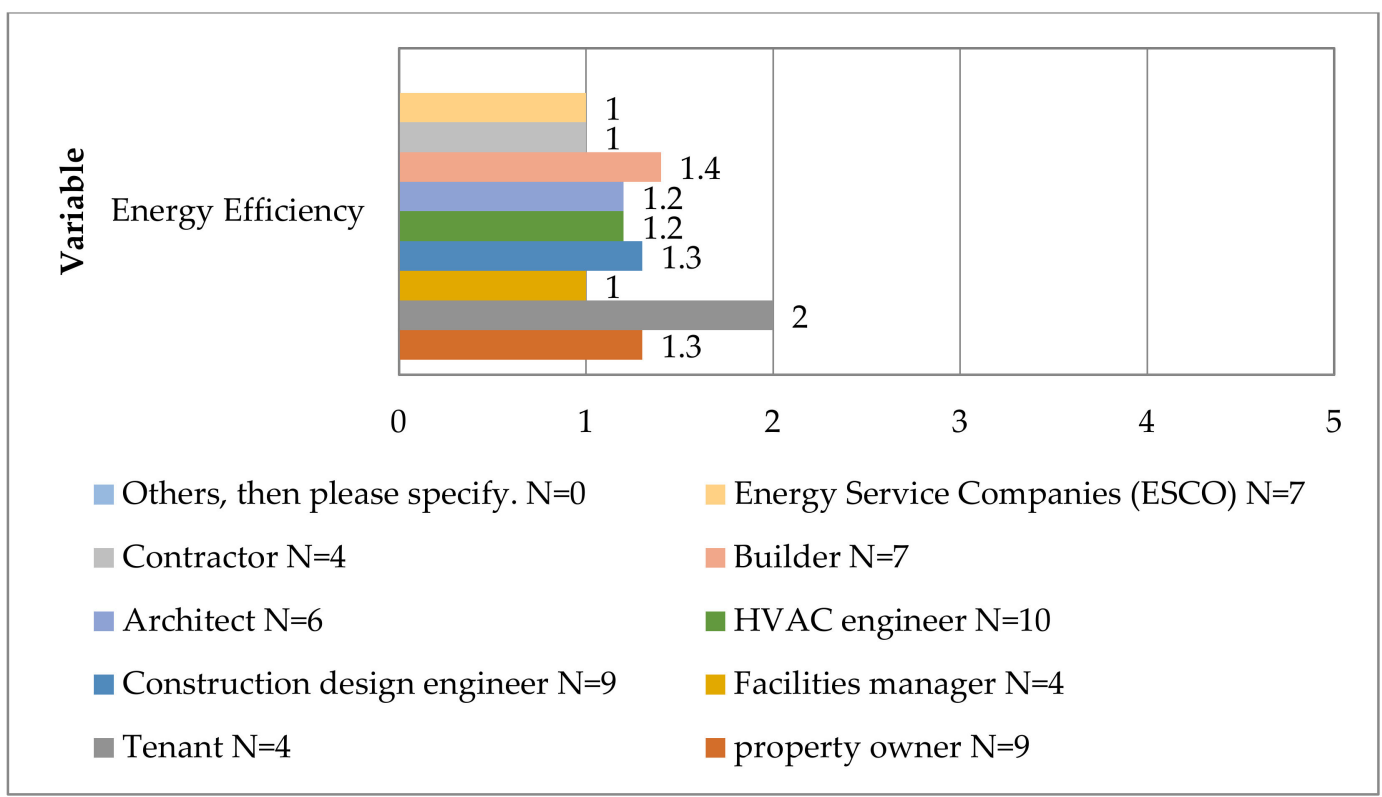

Figure 8. Stakeholders' consideration for the energy efficiency factor toward nearly zero energy buildings.

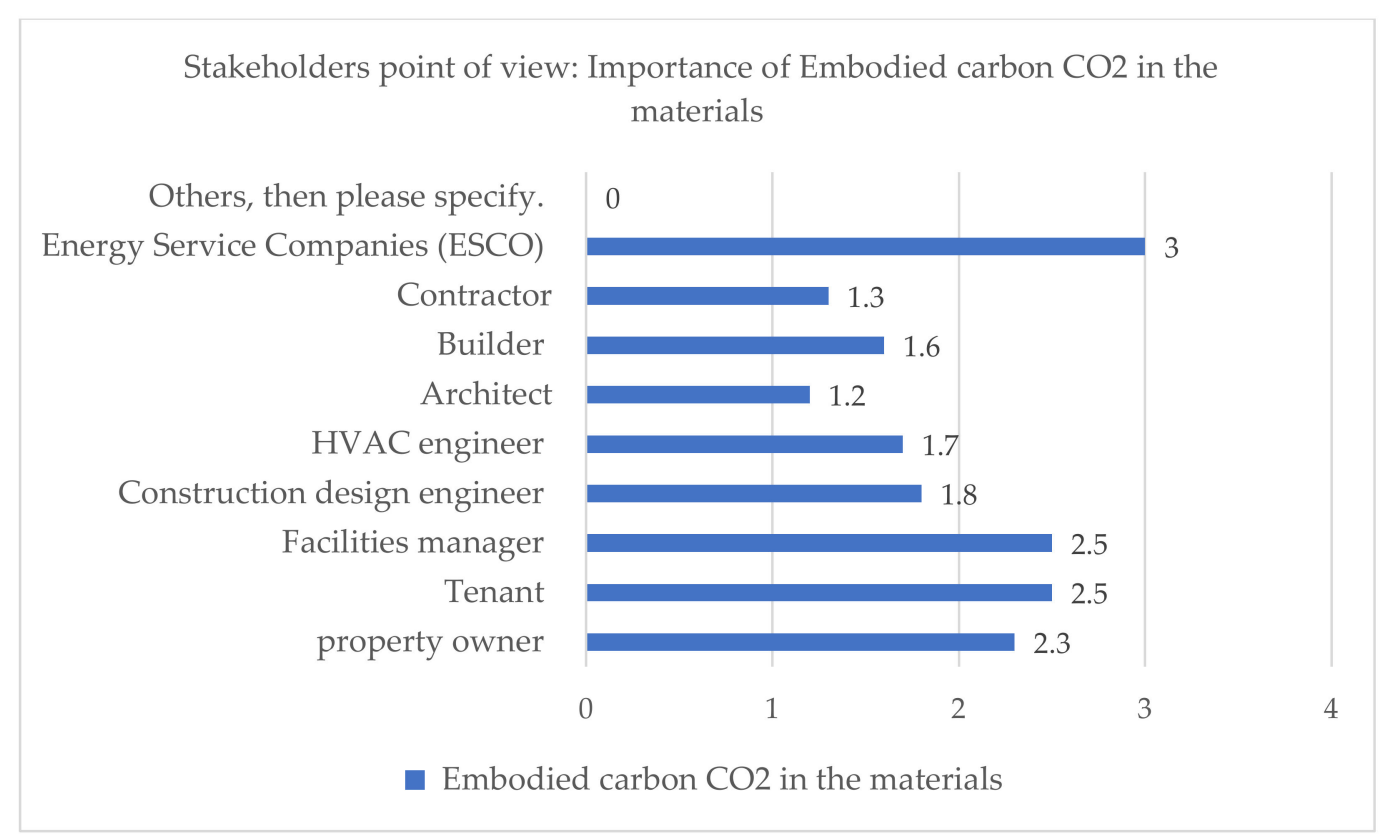

Figure 9. Stakeholders' point of view: importance of embodied carbon $\mathrm{CO}_{2}$ in the materials. 


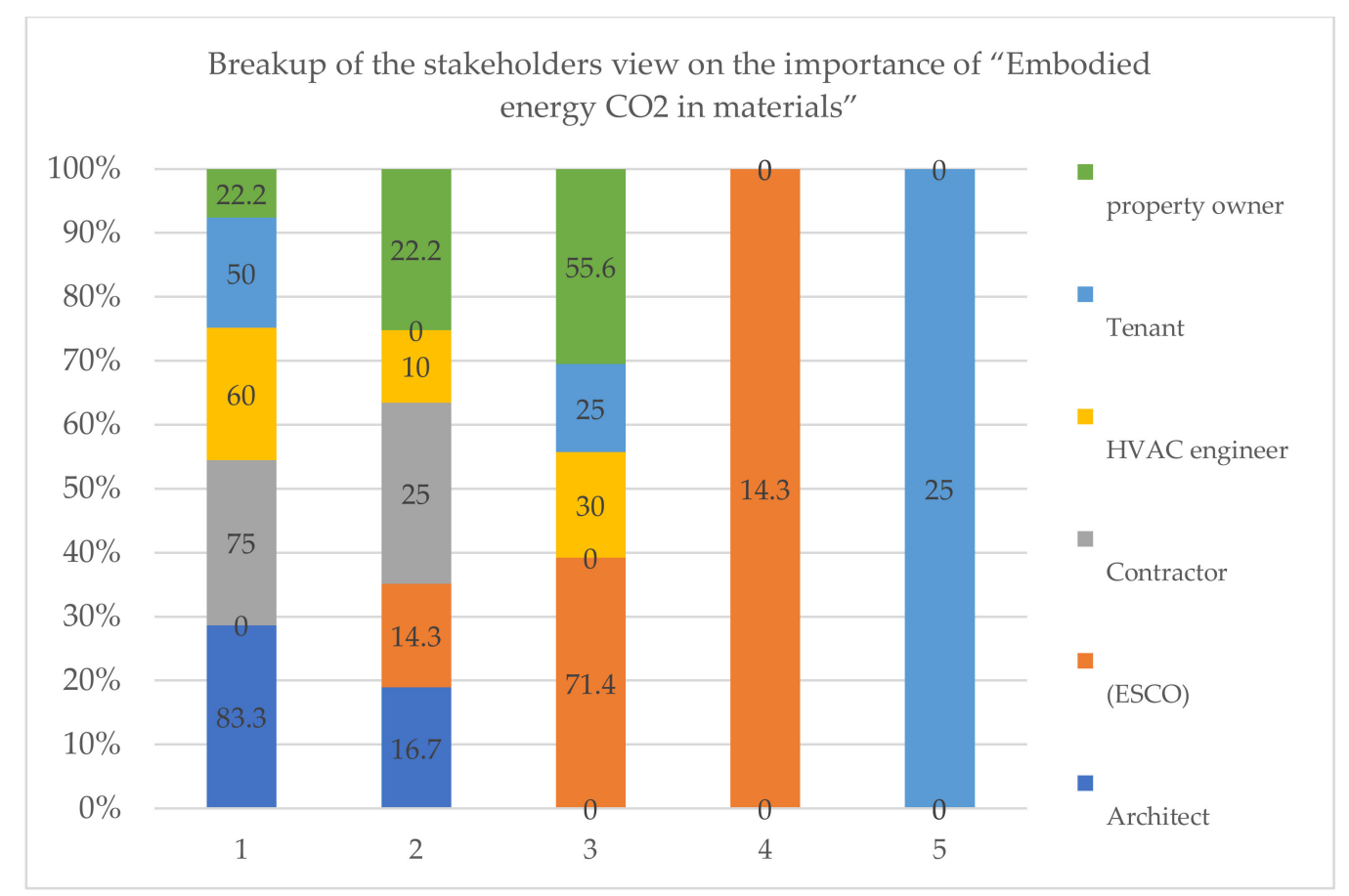

Figure 10. Breakup of the stakeholders view on the importance of embodied energy $\mathrm{CO}_{2}$ in materials.

Figure 10 details the breakup of the stakeholder's point of view on the importance of the embodied energy $\mathrm{CO}_{2}$ in materials, which $83 \%$ of architects ranked as 1 (very important). The remaining $16.7 \%$ of the architects ranked it as 2 (important). Following architects, $75 \%$ and $25 \%$ of the contractors ranked 1 and 2 for the importance of the "embodied energy $\mathrm{CO}_{2}$ in materials", respectively.

\subsubsection{Usage of UN Sustainable Goals}

The representatives of the United Nations met in 2015 to agree on 17 sustainable development priorities including 169 sustainable development objectives in the overall economic, environmental, and social contexts of the countries to be attained by 2030 [42]. To achieve these goals, more effort may be required than the existing policies and strategies. This is particularly true for the energy sector, as energy is the key enabler for all development activities.

Therefore, there is a need to analyze the required usage in the companies from the stakeholder's point of view. Figure 11 shows that approximately $75.6 \%$ do not use SDG goals in their work and $24.6 \%$ of them use it. Furthermore, Figure 12 shows the breakup of the individual stakeholder's usage of the UN sustainable goals. It highlights that the architects, HVAC engineers, and property owners are the ones who most use UN sustainable goals. 


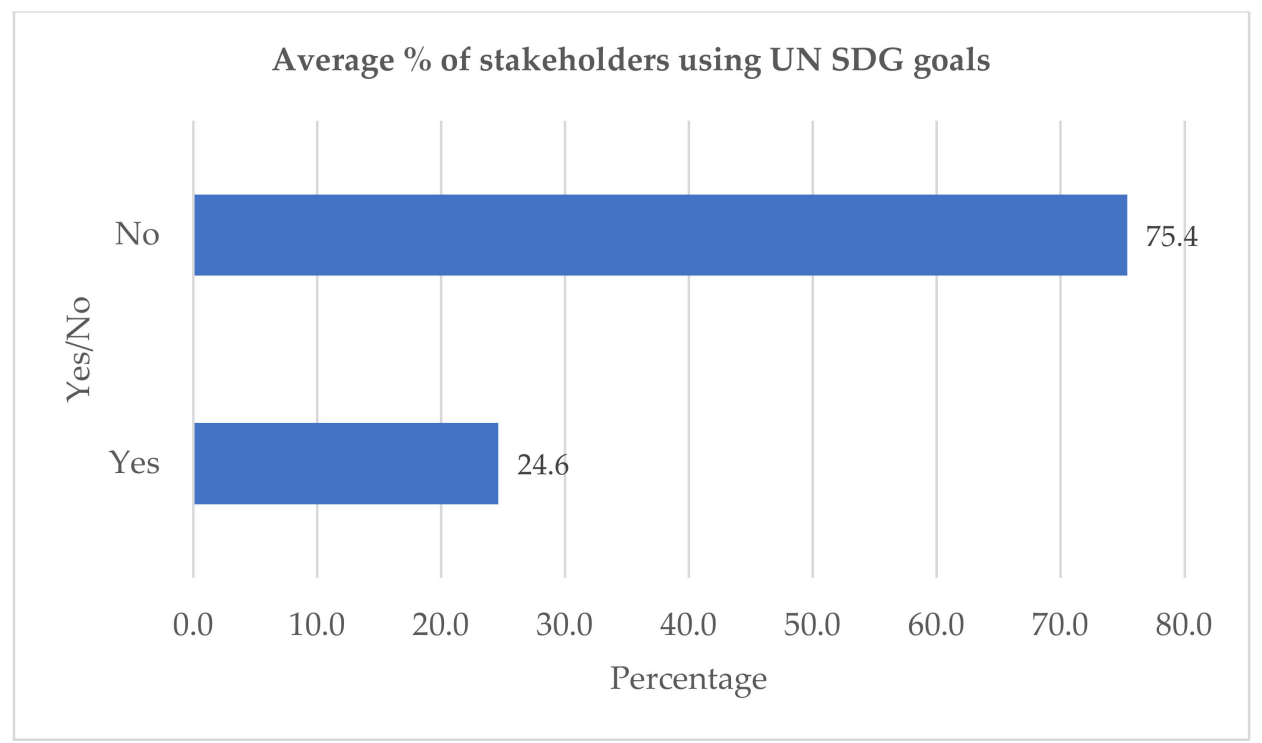

Figure 11. Average percentage of the respondents using UN SDG goals.

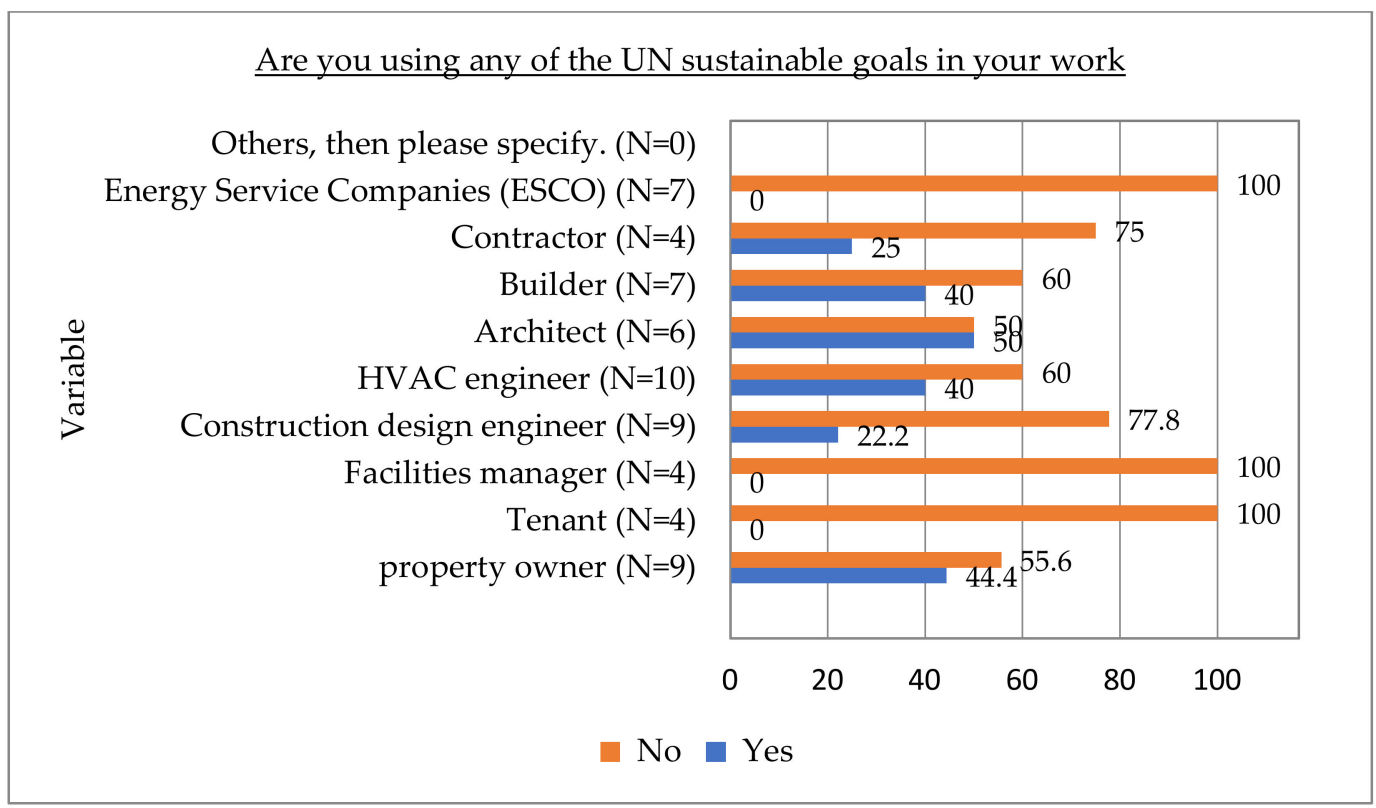

Figure 12. Breakup of the stakeholder's usage of the UN sustainable goals.

Q8 is analyzed further using hierarchical clustering and Sammon mapping. Q8 was an open answer question, and through word mapping (Figure 13), the result highlights that most of the stakeholders indicated that "sustainability" was the most achieved UN goal in their work. The survey shows that the respondents do not have much knowledge about the UN goals, and $75.6 \%$ of the respondents (refer to Figure 11) do not use UN goals in their work. In addition, from their answer of which UN SDG goals they are using, most of them answered "Don't know" among sustainability, some answered that they use energy and architecture related goals, energy, materials, good living, $\mathrm{CO}_{2}$, energy efficiency, sustainability, well-being, and indoor air quality. Among these answers, many of which are related to energy efficiency. Perhaps it seems from their answer that most of them are not aware of the UN sustainable goals. Another option is that they might use more detailed goals than the overarching SDGs in their work. However, Q7 indicates that they give importance to the $\mathrm{CO}_{2}$ embodied carbon. It concludes that they do need training to have knowledge and awareness of UN SDGs. 


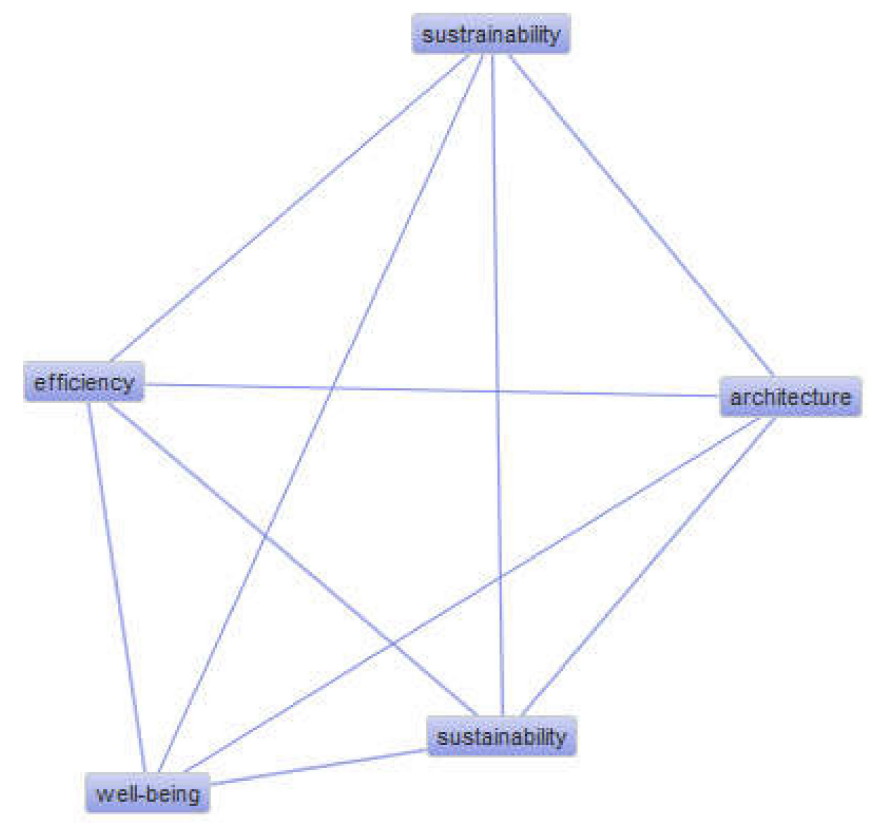

Figure 13. Breakup of the stakeholder's usage of the UN sustainable goals in their work.

4.1.3. The Most Important Actions in Reaching the Carbon Neutrality Target in Building Sector

Carbon neutrality means balancing artificial carbon emissions by compensating with separate emission losses and low $\mathrm{CO}_{2}$ production methods to maintain a net zero-carbon footprint $[43,44]$. At the production stages of carbon emissions, the energy transition required to achieve carbon neutrality is crucial, and energy policy at that point dictates how much emissions are minimized.

When energy-induced carbon emissions cover a substantial part of the overall carbon output of the city or region, energy policies are much more important.

In addition to the Helsinki Municipal Environmental Services Authority (HSY), the cities in the Helsinki Metropolitan Area have set clear targets to become carbon-neutral by 2050. Q10 assesses the stakeholder's attitude and approaches toward the carbon neutrality in the building sector.

When selecting key steps to meet the carbon neutrality objective in the building sector, (refer Figure 14) the following have been ranked 1 (very important) by the stakeholders: (a) the use of smart technologies for reducing running time carbon emissions, (b) the use of renewable energies, (c) both embodied and running time carbon emissions. However, "Embodied carbon in materials" has been ranked 2 (important).

Figure 15 shows the stakeholders' view in terms of ranking of the "embodied carbon in materials". It highlights that for the stakeholders such as architects and contractors, "embodied carbon in materials" is very important. The majority (65\%) of the architects and the contractors ranked 1 for embodied carbon in the building, followed by $50 \%$ of the tenants and $44 \%$ of the construction design engineers. Perhaps we might infer that "embodied carbon in material" is very relevant to architects, contractors, and construction engineers. The remaining stakeholders-property managers, facility managers, energy service companies, etc.-ranked 3 (rather unimportant), which somehow stresses that these stakeholders are not bothered about the embodied carbon in materials, or it might be because of the lack of awareness about the embodied carbon in materials. Architects and contractors are the ones interested in embodied $\mathrm{CO}_{2}$, while facility managers, etc., are not the ones selecting the materials, which is probably why they are not so interested in embodied $\mathrm{CO}_{2}$. 


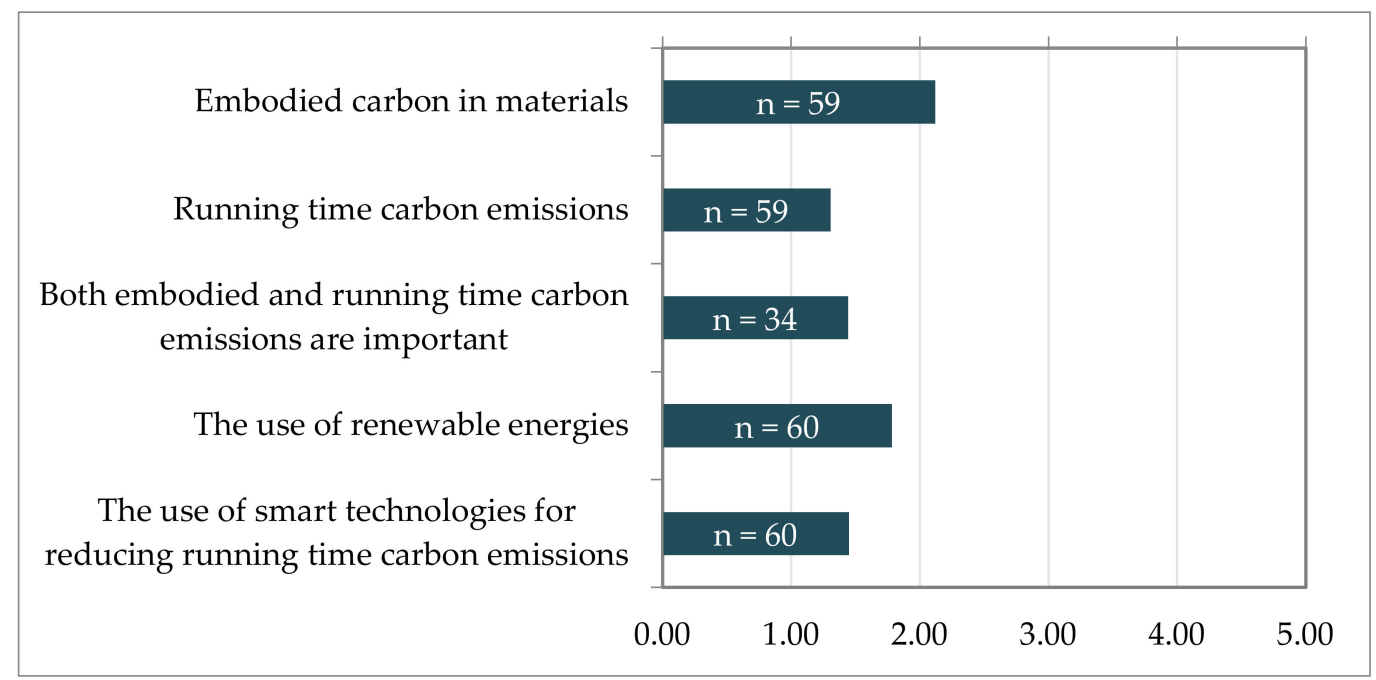

Figure 14. Ranking of the important actions in reaching the carbon neutrality target in the building sector.

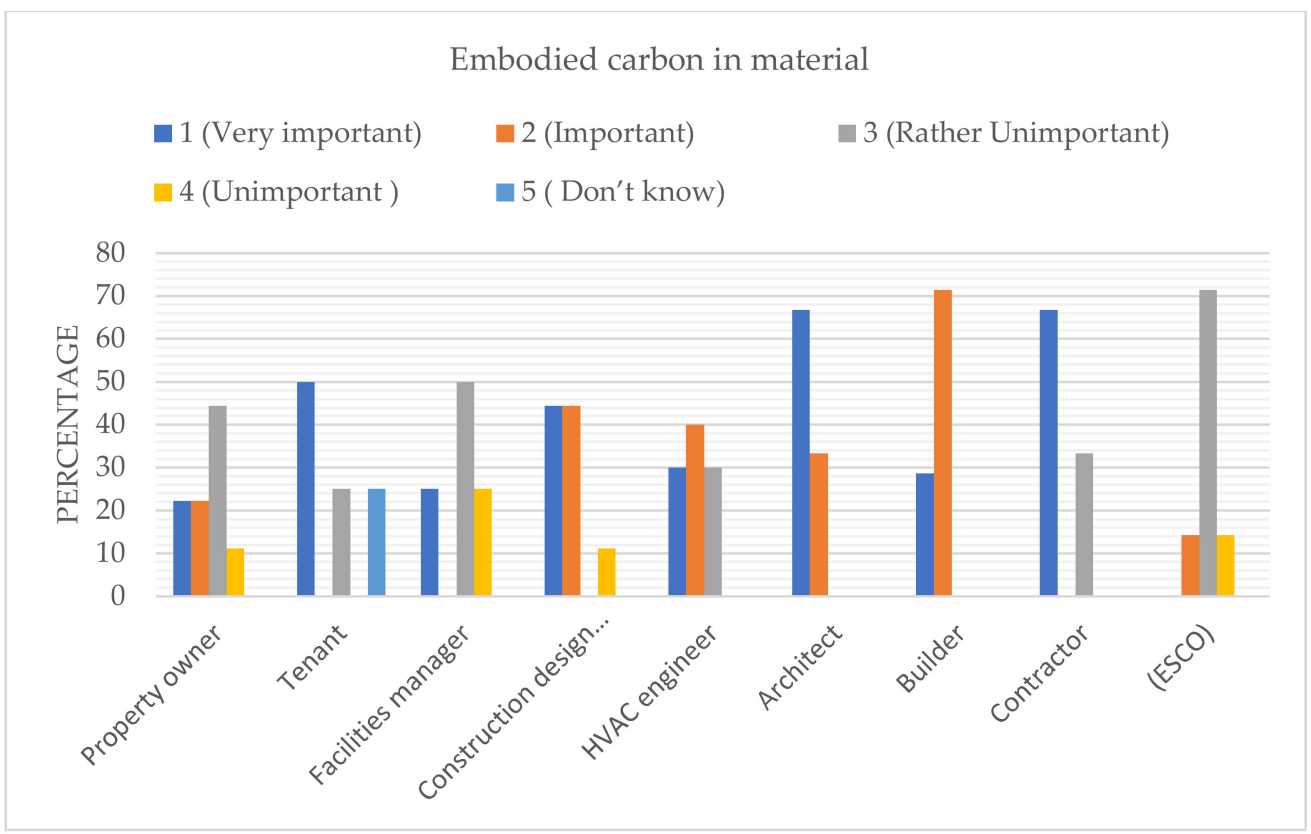

Figure 15. Stakeholder's ranking for "embodied carbon in material" for reaching the carbon neutrality target in the building sector.

Embodied carbon in materials during the design stage is also a significant step toward designing the nZEB buildings. Chastas et al. [45] studied a sample of 90 case studies of residential buildings from the viewpoint of life cycle energy. The findings suggest an embodied share of energy for traditional built buildings of 6-20\%, passive energy building of $11-33 \%$, low-energy buildings of $26-57 \%$, and nearly zero energy buildings of $74-100 \%$.

Sartori and Hestnes [46] found that the embodied energy accounted for $2-38 \%$ of traditional building life cycle energy and 9-46\% of a low-energy building life cycle energy.

Figure 16 highlights that the "running time carbon emissions" is very important for property owners $(78 \%)$, tenants $(75 \%)$, facilities managers $(75 \%)$, construction design engineers $(67 \%)$, and HVAC engineers (90\%). Nevertheless, it is splendid to see that $100 \%$ of the contractors and ESCO companies ranked 1 for the importance of "running time carbon emissions" in reaching the carbon neutrality in the building sector. It is very fascinating to see from the survey that "running time carbon emissions" has been ranked 1 (very important) and 2 (important) by all stakeholders. None of them ranked 3, 4 or 5; moreover, 
it confirms that stakeholders take seriously running time carbon emissions toward nearly zero energy buildings. However, it is very surprising that landlords have no view about the importance of carbon neutrality in the buildings. In another way, we can assume that landlords do not realize the significance of carbon neutrality in buildings.

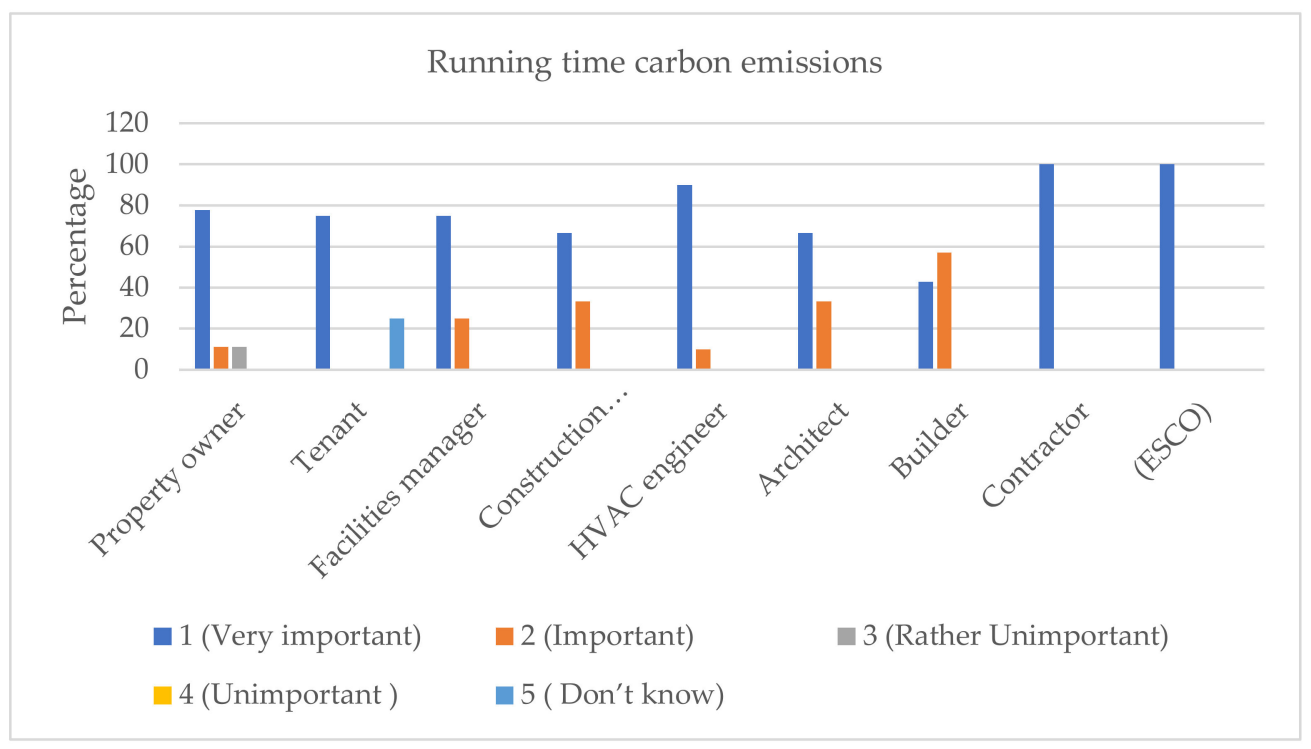

Figure 16. Stakeholder's ranking for the "running time carbon emissions" in reaching the carbon neutrality target in the building sector.

Furthermore, the construction professionals were asked to rate the requirement of "both embodied and running time carbon emissions" across five categories in order of their importance (Figure 17). A very stagnant response to these actions in reaching the carbon neutrality target in the building sector indicates a high appetite for both embodied and running time carbon emissions by construction professionals in the Finnish retrofit industry.

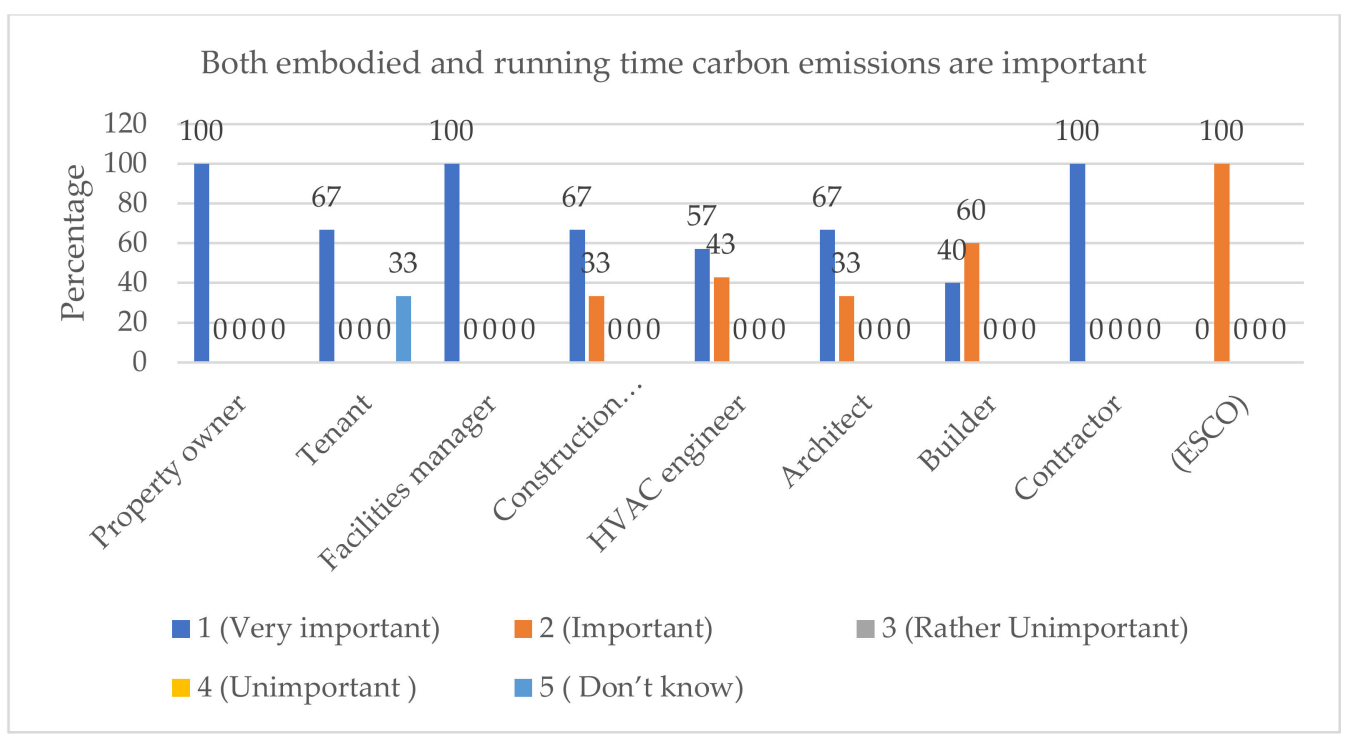

Figure 17. Stakeholder's ranking for the "Both embodied and running time carbon emissions are important" in reaching the carbon neutrality target in building sector.

Furthermore, there has been a diverse trend observed for the importance of "renewable energy" (Figure 18) and "the use of smart technologies for reducing running time carbon emissions" (Figure 19) toward carbon neutrality across five categories. When it comes 
to the use of "renewable energy", most of the stakeholders ranked it as very important. ESCOs, tenants, HVACs, and architects are among the highest respondents who ranked it as very important. Nevertheless, there are some construction professionals such as property owners, facilities managers, construction design engineers, and builders who ranked it as rather unimportant.

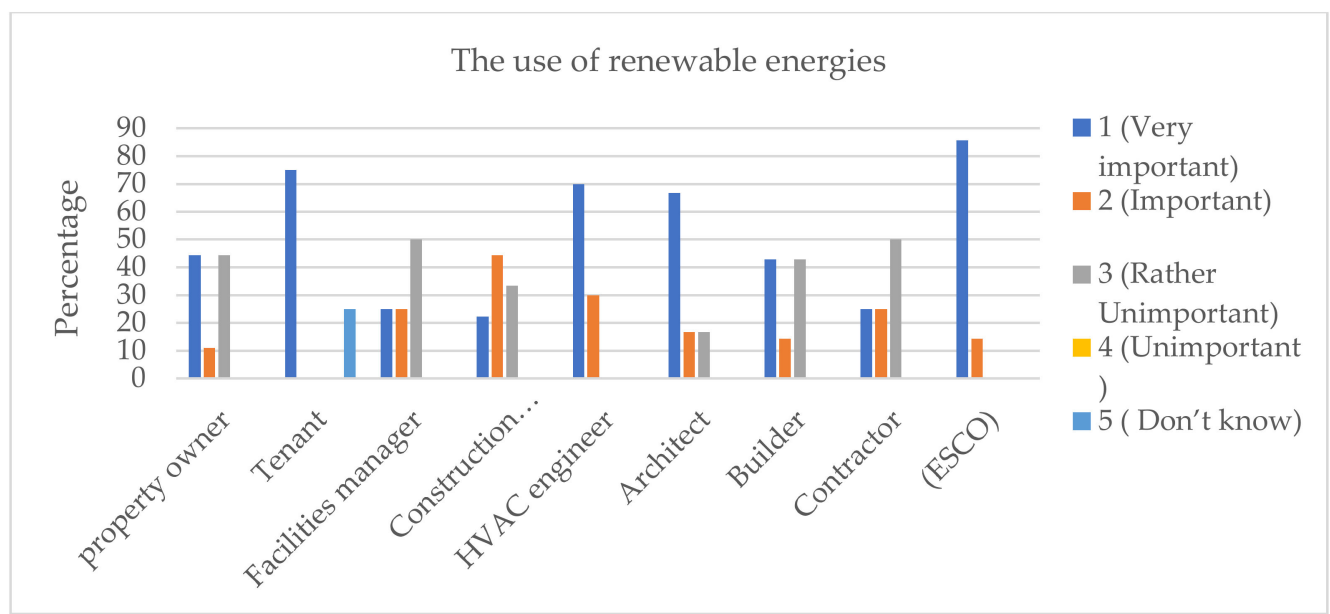

Figure 18. Stakeholder's ranking for the "the use of renewable energies" in reaching the carbon neutrality target in the building sector.

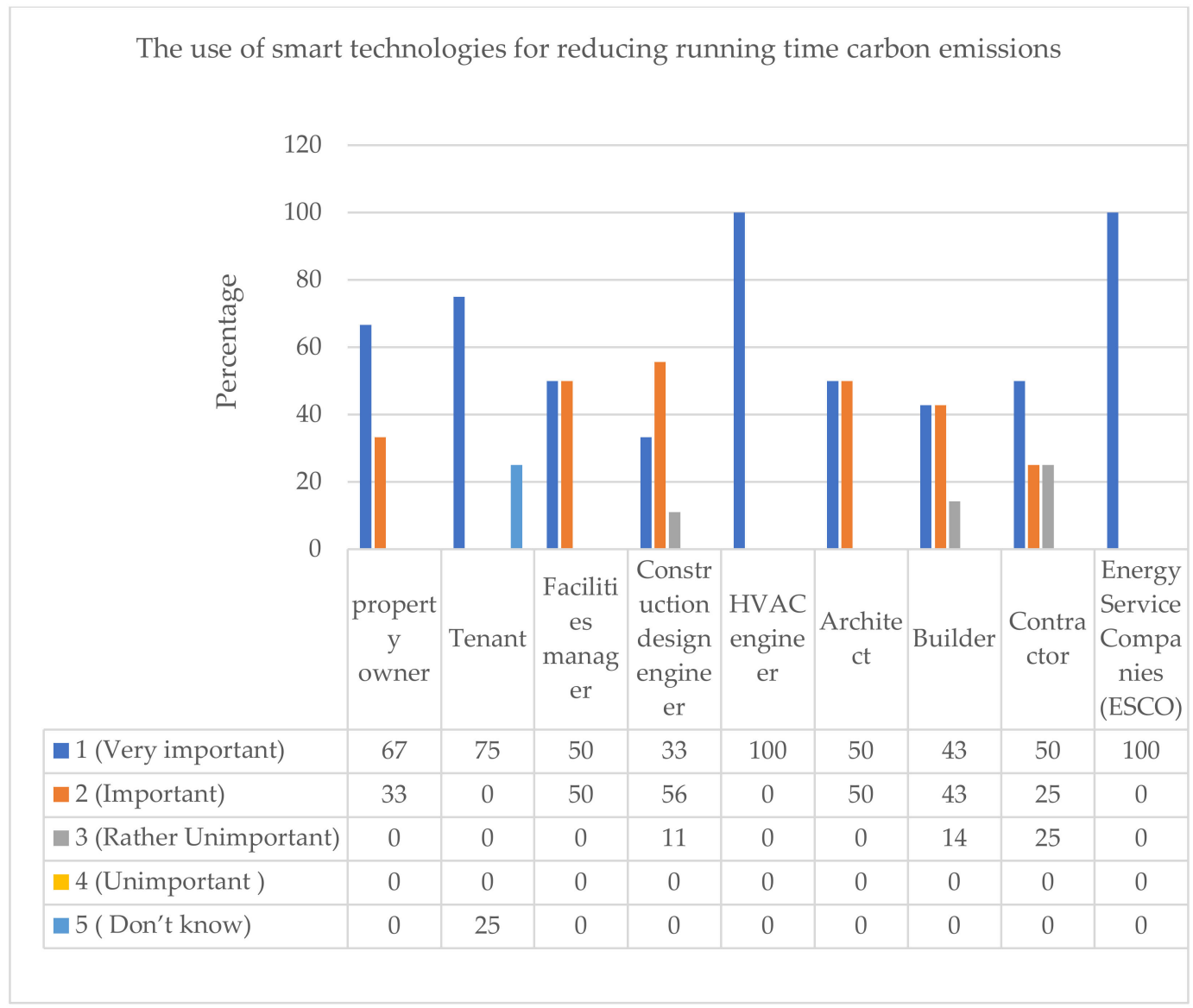

Figure 19. Stakeholder's ranking for the "the use of smart technologies for reducing running time carbon emissions" in reaching the carbon neutrality target in the building sector. 
Renewable energy policies are necessary for achieving carbon neutrality, which is the main goal for climate change mitigation. The cities in Helsinki have vowed to drastically reduce carbon emissions through numerous climate initiatives, including some renewable energy use initiatives [47]. However, the findings of the authors of [48] show that current renewable energy policies in the Helsinki metropolitan area are weak and many challenges exist. Nevertheless, various ways to strengthen current practices are available.

The use of smart technologies for reducing running time carbon emissions is very important among ESCOs, HVACs, tenants, and property owners followed by facilities managers, architects, builders, and contractors. However, it is very much interesting to see the trend in which half of the architects, facilities managers, and builders rank it as merely important.

\section{Interview Results: Investigating the Key Personnel}

In-depth interviews were conducted as the final component of this study on retrofit practices. The interviews were semi-structured of 30-60 min duration, which gave the interviewees the freedom to share their thoughts, ideas, and experiences. Interview questions focused on the $\mathrm{CO}_{2}$ emissions and $\mathrm{CO}_{2}$ emissions in the construction phase: (1) what do they prioritize and why? (2) What kind of tools or targets would be useful to support resiliency and sustainability in their work? (3) Are they using UN Sustainable Development Goals in their work as guiding tool? (4) What is their attitude toward nZEB? The aim of this phase of the study was to interview the process actors as widely as possible.

The results of the interviews are based on responses to open-ended questions which reflected the independent perspective of the interviewees. A thematic analysis was conducted to analyze the results. A total of four interviews were conducted, and participants were selected randomly from different backgrounds and practices in renovation and refurbishment activities in buildings following a purposeful sampling technique.

\subsection{Usage of UN Goals in the Work as a Guiding Tool}

"Yes, they are using UN development sustainable goals. However, they don't think about it daily, weekly or monthly basis, it is just there. Their strategy is linked to [the] UN (climate goal) to their sustainable implementation towards [becoming] carbon neutral". (sustainable development manager)

"Yes, we have chosen specific targets"

"Yes, we do use [the SDGs] as a guiding tool but not [in] a strategic way. We have done a quick mapping which of these SDGs are relevant to work. We have used as a very broad guideline. We use it because it's a good picture which gives a broad way. However, it's a bit difficult to pick one SDGs as it is very broad, it is good for big business."

"It is an established frame, no we don't use SDGs in our work". (sustainable manager)

Overall Comment: In a deeper sense they are using UN SDGs as a guiding tool and more on strategic levels. However, they were not using detailed policy.

\subsection{Assessment $\mathrm{CO}_{2}$ Emissions in Construction Phase}

“We as a program, we don't building anything, we don't build buildings. We are making a roadmap for buildings to become carbon neutral. We need to reduce the carbon emissions during both [the] running and construction phase. We do recognize that running time gives more carbon emissions and we have to tackle both. However, when we build something new, we have to focus on [the] construction phase". (development manager)

“We prioritize operation time, because that's we know and it's easier to calculate and easy to affect us directly. In the construction phase, we have not constructed yet. It might come with a huge price tag so it's a little bit tough for us. Maybe if 
some construction provider comes to us saying that they will give us some help, then we may can think about it. In the longer run the emissions [come] from the construction [rather] than in the operation phase."

"Both are important, ours has promised to be $\mathrm{CO}_{2}$ free by 2045."

"I would talk about embodied, running time is a big part of the life cycle. Of course the materials' impact is increased. Structural energy is also important. It is very difficult to prioritize."

Overall Comment: For them, the embodied running time is more important as it is a big part of the material lifecycle. Most of them have not factored in the construction phase, as it might come with a huge price. However, if the construction provider could provide some help, they might think about it. In longer run, the emissions from the construction is more important than in the operation phase.

\subsection{Tools or Targets to Support Resiliency and Sustainability in Their Work}

"The calculator, the national target on how you calculate and what. We can't think of one specific tool. In terms of target, we already have, as it's already in the city strategy to support the resiliency and sustainability in the work."

"We follow all different kinds of energy consumptions we have. We would be interested in understanding better the visitor and logistics carbon emissions."

"We are using modeling and target values/criteria for design. We have our own $\mathrm{CO}_{2}$ calculation models and we are using them to set the targets for our projects."

"We use many kinds of tools, like EPDs. We can see the impacts from one-click LCA software and the carbon designer tool, we can utilize when we have EPDs."

Overall Comment: They have not used any specific tool to support resiliency and sustainability in their work. They have their own $\mathrm{CO}_{2}$ calculation models and are using them to set the targets for their projects. However, they can not think of any one specific tool.

\subsection{Attitudes toward nZEB}

"We think nZEB buildings are [one] more step to going toward negative building. Looking at the city perspective, it's a good attitude; however, in a bigger picture, it requires [the] collaboration of all the stakeholders. Communication and collaboration are vital parts in accomplishing these targets toward the city NZEB. Financing part also comes [into the] picture, it has to be viable to make the buildings nZEBs, those are businesses and they have to make money". (development manager)

"nZEB is possible, [the] EU definition is different than any other countries. For example, each climate has different criteria. We are constructing right now. Buildings [that] produce their own energy is tough though". Producing all the energy on site is not feasible. Everything comes with a price tag but not all is possible."

"It is really happening. We are promoting a lot, it's our business to promote."

"We focus on zero carbon buildings, zero energy is good but not enough".

Overall Comment: Looking at the bigger picture, nZEB needs the collaboration of all the stakeholders. Designing nZEBs is possible; however, producing all the energy on site is not feasible. Stakeholders are focusing on zero carbon buildings.

Furthermore, the findings were collated in each theme to present the overall picture. Quotations have been used to improve the interpretation of the findings.

\section{Summary of the Results and Discussion}

The aim of this paper is to identify the attitudes, approaches, and experiences of Finnish construction professionals regarding energy-efficient buildings, particularly nZEBs. 
To accomplish this, we used a two-tier approach: (a) an online survey questionnaire methodology and (b) interviews with the personnel, which considered various users segment groups, in the financial community and among sellers. Questions for the questionnaire are divided into four different categories: the individual perspective, the SDGs perspective, the materials' embodied carbon perspective, and the market energy-efficiency perspective. The total number of the respondents was 60 . Approximately $35 \%$ of the respondents were in the age range of 36-46 followed by the age group of $47-57$ with $32 \%$. Most of the participants as stakeholders were HVAC engineers $(16 \%)$, followed by the largest group of participants, construction design engineers $(15 \%)$ and property owners $(11 \%)$. The other largest groups were ESCOs $(12 \%)$, builders $(11 \%)$, architects $(10 \%)$, tenants, facility managers, and contractors with $7 \%$ each.

\subsection{Stakeholders Attitudes toward Importance of Energy Efficiency and Embodied $\mathrm{CO}_{2}$}

The results show that the importance of the embodied carbon $\mathrm{CO}_{2}$ in the materials is less important than the energy efficiency from the stakeholder's point of view. Figure 9 highlights that "energy efficiency" is very important for ESCOs, contractors, and facility managers followed by architects, HVAC engineers, and construction design engineers.

When it comes to the responses of the importance of the "embodied energy $\mathrm{CO}_{2}$ " toward nearly zero energy buildings (refer to Figure 10), the survey results highlighted that for architects, the importance of the embodied energy $\mathrm{CO}_{2}$ ranked the highest. Figure 11 further shows that $83.3 \%$ of architects ranked 1 (very important) and $16.7 \%$ of them ranked 2 (which is important). As the architects are the designers of the buildings, embodied $\mathrm{CO}_{2}$ makes sense for them. However, it seems that for other stakeholders e.g., facility managers, tenants, property managers, and ESCOs, the importance of the embodied carbon is rather unimportant. It can be concluded from this result that these stakeholders might not be properly aware of the significance of embodied carbon in materials.

Several studies highlight that embodied carbon makes up between 27 and $58 \%$ of lifecycle carbon emissions [49]. In terms of building components, Hughes and Winter [50] have shown that the selection of the structural frame system has a more significant influence on the embodied carbon and cost than other building components such as (structural frame, inner components (i.e., insulation and sheathing). Hence, it is very important for the stakeholders to understand the importance of expressing and understanding the diversity of the materials.

\subsection{Usage of the UN Sustainable Goals in Your Work}

Figure 13 shows the breakup of the individual stakeholder's usage of the UN sustainable goals. It highlights that the architects, HVAC engineers, and property owners are the ones who consider the most usage of UN sustainable goals. This justifies the results from Q7 (where architects indicate the importance of embodied carbon in the material), as the building materials can contribute significantly to the achievement of UN goals [51]. The results presented in this research [52] proved that building materials can contribute significantly to the achievement of the 13 goals and 25 targets of the SDGs. The framework showed that a direct positive contribution of building materials on the SDGs has been noticed in SDG 3, SDG 7, SDG 9, SDG 11, SDG 12, SDG 13, and SDG 15 . However, the survey taken in this research study shows that the respondents do not have much knowledge about the UN goals, and $75.6 \%$ of the respondents (refer Figure 12) do not use UN goals in their work.

\subsection{Importance of Carbon Neutrality Reaching the nZEB}

Q10 assesses the stakeholder's attitudes and approaches toward carbon neutrality in the building sector. This question was subdivided into ranking the opinion toward the most important actions in reaching the carbon neutrality targeting the building sector. The important actions were listed as follows: (1) embodied carbon in materials, (2) running time carbon emissions, (3) both embodied and running time carbon emissions, (4) the use 
of renewable energies, and (5) the use of smart technologies for reducing running time carbon emissions.

Overall, the tenants, HVAC engineers, architects, and the ESCOs among the overall stakeholders seem aware of the nZEBs. In terms of the use of renewable energy (Q10) in nZEBs, tenants, HVAC engineers, architects, and ESCOs have listed it as the most important.

The reason behind the awareness could be the direct involvement in the construction of the buildings. However, property owners, facilities managers, construction design engineers, builders, and contractors ranked the usage of renewable energies as rather unimportant. Nevertheless, when it comes to the knowledge of energy efficiency, the survey [51] highlighted that most of the respondents consider renewable energy technologies (RETs) such as solar PV as one the energy-efficiency options among others such as solar hot water, nuclear power, power plant, wind energy, solar power plants, etc.

Renewable energy policies are necessary for achieving carbon neutrality, which is the main goal for climate change mitigation. The cities in the Helsinki metropolitan area have pledged themselves, through different initiatives on climate change and several measures for renewable energy utilization, to substantially reduce emissions of carbon [47]. However, the findings of [47] show that current renewable energy policies in the Helsinki metropolitan area are weak and many challenges exist. Nevertheless, numerous options to strengthen current practices are available.

The research study concludes that in the case of net zero energy buildings, the main impact occurs due to the building materials and technologies installed on the site [53].

The overall collective picture represents the attitudes and approaches of the industry stakeholders that define the shape and growth of the industry for future nZEBs.

\section{Discussion}

In Finland, an energy transition to a carbon neutral society appears as a unifying sociotechnical imaginary shared by politicians at different levels. While the imaginary is precise, with carbon neutrality as a long-term societal goal to be achieved in 2050, it is also interpretatively flexible, as carbon neutrality accommodates multiple views on the role of acceptable technologies, energy sources, and offsets [54].

This paper is present the attitudes of the stakeholders on nZEB in the Finnish region. The research highlights that "energy efficiency" is very important for ESCOs, contractors, and facility managers followed by architects, HVAC engineers, and construction design engineers. However, when it comes to "embodied carbon in materials", ESCOs followed by tenants and facility managers rank it as unimportant. When it comes to the use of renewable energy, most of the stakeholders ranked it as very important. ESCOs, tenants, HVACs, and architects are among the highest respondents who ranked it as very important. Nevertheless, there are some construction professionals such as property owners, facilities managers, construction design engineers, and builders who ranked it as rather unimportant. The primary objective of the facilities manager is to oversee the maintenance and upgrading of the built-in environment of a specific workplace. A facilities manager needs to integrate the employees of the firm with the dynamics of the infrastructure on a single integrated platform. However, the current changes, particularly in the sustainability area sparked by the climate changes, have also changed the roles and duties of facilities managers [55]. As described by Goyal et el. [56], the future importance of facility managers will enhance cost-effective and environmental issues which is becoming the main concern in every field of economic activity.

The results highlight that the "running time carbon emissions" is very important for property owners $(78 \%)$, tenants $(75 \%)$, facilities managers $(75 \%)$, construction design engineers (67\%), and HVAC engineers (90\%). Nevertheless, it is splendid to see that $100 \%$ of the contractors and ESCO companies ranked 1 for the importance of "Running time carbon emissions" in reaching carbon neutrality in the building sector. Perhaps it is very fascinating to see from the survey that "running time carbon emissions" has been ranked 
1 (very important) and 2 (important) by all stakeholders. None of them ranked 3, 4, or 5; moreover, it confirms that stakeholders take seriously running-time carbon emissions toward nearly zero energy buildings.

Overall, the tenants, HVAC engineers, architects, and the ESCOs among the overall stakeholders seems aware of the nZEBs. They also ranked the renewable energy as very important toward achieving nZEBs. Among the various stakeholders, it can be summarized that the stakeholders are aware of renewable energy and its importance toward achieving nZEB. Deng et al. [56] introduced several promising and renewable energy-efficient measures for NZEB, such as solar heating systems, solar cooling systems, renewable source heat pumps, and power generation systems. Ref. [14] defined the priorities for a ZEB: the first factor was the question of energy efficiency and then the application of renewable energy sources.

Renewable energy policies are necessary for achieving carbon neutrality, which is the main goal for climate change mitigation. The cities in Helsinki have vowed to drastically reduce carbon emissions through numerous climate initiatives, including some renewable energy use initiatives [47].

Detailed guidebooks, practical examples, and comprehensive training are essential for consumers as well as professionals to take up nZEB.

Future research tasks can involve the attitudes of the stakeholders focusing on countryspecific case studies, identifying the key barriers, gaps, and challenges. Together, this shall provide a holistic view of results in this direction. The overall worldwide collective picture can represent the attitudes and approaches of the industry stakeholders that define the shape and growth of the industry for future nZEBs.

Supplementary Materials: The following are available online at https:/ / www.mdpi.com/article/10 $.3390 /$ su13137359/su13137359/s1.

Author Contributions: Formal analysis, S.A.; Investigation, S.A.; Resources, S.A.; Software, S.A.; Conceptualization, S.A.; methodology, S.A.; validation, S.A.; formal analysis, S.A.; investigation, S.A.; resources, S.A.; writing—original draft preparation, S.A.; writing—review and editing, S.A. and M.A.; visualization, S.A.; supervision, R.L. All authors have read and agreed to the published version of the manuscript.

Funding: Sadaf Alam was supported by a doctoral fellowship through Dean of Aalto Engineering Doctoral programme. This research work received Aalto university, Mechanical department financial support for the open access publication.

Institutional Review Board Statement: Not applicable.

Informed Consent Statement: Not applicable.

Data Availability Statement: Not applicable.

Acknowledgments: The authors gratefully acknowledge all the participants of the survey, workshop. The authors would like to thank the reviewers for all their careful, constructive and insightful comments in relation to this work.

Conflicts of Interest: The authors declare no conflict of interest.

\section{References}

1. Zhao, X.; Pan, W.; Lu, W. Business model innovation for delivering zero carbon buildings. Sustain. Cities Soc. 2016, 27, 253-262. [CrossRef]

2. Zuo, J.; Read, B.; Pullen, S.; Shi, Q. Achieving carbon neutrality in commercial building developments-Perceptions of the construction industry. Habitat Int. 2012, 36, 278-286. [CrossRef]

3. European Commission. Stepping up Europe's 2030 climate ambition: Investing in a climate-neutral future for the benefit of our people. J. Chem. Inf. Model. 2020, 53, 1689-1699.

4. Warf, B. Energy Technologies. 2017. Available online: https://www.elgaronline.com/view/edcoll/9781785361159/978178536115 9.xml (accessed on 14 May 2021). 
5. Hamdy, M.; Mohamed, A.; Hasan, A. Net- and Nearly- Zero Energy Buildings: A Review of the Definitions and Case Studies. In Proceedings of the Sixth International Conference on Heating, Ventilation and Air-Conditioning, RIPI Conventions Center, Tehran, Iran, 26-28 May 2015; ICHVAC6-8112.

6. Paatero, J.V.; Moula, M.E.; Alanne, K. Occupants' acceptability of zero energy housing in Finland. Int. J. Sustain. Energy 2019, 38, 542-560. [CrossRef]

7. González, M.J.; Navarro, J.G. Assessment of the decrease of $\mathrm{CO}_{2}$ emissions in the construction field through the selection of materials: Practical case study of three houses of low environmental impact. Build. Environ. 2006, 41, 902-909. [CrossRef]

8. Ministry of Economic Affairs and Employment. Finland's Integrated Energy and Climate Plan; Ministry of Economic Affairs and Employment: Helsinki, Finland, 2019.

9. Marszal, A.J.; Bourrelle, J.; Musall, E.; Heiselberg, P.; Gustavsen, A.; Voss, K. Net Zero Energy Buildings-Calculation Methodologies Versus National Building Codes. EuroSun 2016, 2, 1-8.

10. Sartori, I.; Napolitano, A.; Voss, K. Net zero energy buildings: A consistent definition framework. Energy Build. 2012, 48, 220-232. [CrossRef]

11. Programmes, N.R. Directive 2012/27/Eu Of The European Parliament And Of The Council of 25 October 2012 on energy efficiency, amending Directives 2009/125/EC and 2010/30/EU and repealing Directives 2004/8/EC and 2006/32. Off. J. L. 2012, $315,1-56$.

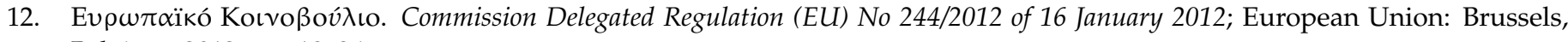
Belgium, 2012; pp. 18-36.

13. European Union. Directive 2010/31/EU of the European Parliament and of the Council of 19 May 2010 on the Energy Performance of Buildings; European Union: Brussels, Belgium, 2010; pp. 1-25.

14. Crawley, D.; Torcellini, P.; Tournaki, S. Zero Energy Buildings: A Critical Look at the Definition; National Renewable Energy Laboratory: Golden, CO, USA, 2006; Volume 126, p. 368.

15. Congedo, P.M.; Baglivo, C.; D'Agostino, D.; Zacà, I. Cost-optimal design for nearly zero energy office buildings located in warm climates. Energy 2015, 91, 967-982. [CrossRef]

16. Zacà, I.; D’Agostino, D.; Congedo, P.M.; Baglivo, C. Assessment of cost-optimality and technical solutions in high performance multi-residential buildings in the Mediterranean area. Energy Build. 2015, 102, 250-265. [CrossRef]

17. Zacà, I.; D'Agostino, D.; Congedo, P.M.; Baglivo, C. Data of cost-optimality and technical solutions for high energy performance buildings in warm climate. Data Br. 2015, 4, 222-225. [CrossRef]

18. Zacà, I.; D'Agostino, D.; Congedo, P.M.; Baglivo, C. Cost-optimal analysis and technical comparison between standard and high efficient mono-residential buildings in a warm climate. Energy 2015, 83, 560-575.

19. Zacà, I.; D'Agostino, D.; Congedo, P.M.; Baglivo, C. Efficient solutions and cost-optimal analysis for existing school buildings. Energies 2016, 9, 1-24.

20. Annunziata, E.; Frey, M.; Rizzi, F. Towards nearly zero-energy buildings: The state-of-art of national regulations in Europe. Energy 2013, 57, 125-133. [CrossRef]

21. Roelens, W.; Loncour, X. Enforcing Energy Performance Requirements in New and Refurbished Buildings Requirements in New and Refurbished Buildings. 2014. Available online: http:/ /www.epbd-ca.eu/wp-content/uploads/2011/05/CA-EPBDenforcement-of-requirements.pdf (accessed on 14 April 2021).

22. European Commission. Directive 2010/31/EU; European Commission: Brussels, Belgium, 2010; pp. 13-35.

23. Kylili, A.; Fokaides, P.A. European smart cities: The role of zero energy buildings. Sustain. Cities Soc. 2015, 15, 86-95. [CrossRef]

24. Staniaszek, D.; Kockat, J.; Vitali Roscini, A. A Review of EU Member States 2020 Long-Therm Renovation Strategies; BPIE: Brussels, Belgium, 2020.

25. European Commission. National Plans for nearly Zero-Energy Buildings; European Commission: Brussels, Belgium, 2015 ; p. 24.

26. Heiskanen, E.; Matschoss, K.; Kuusi, H. Intelligent Energy Europe: Report on specific features of public and social acceptance and perception of nearly zero-energy buildings and renewable heating and cooling in Europe with a specific focus on the target countries. Renew. Sustain. Energy Rev. 2012, 75, 580-591. [CrossRef]

27. Risholt, B.; Time, B.; Grete, A. Sustainability assessment of nearly zero energy renovation of dwellings based on energy, economy and home quality indicators. Energy Build. 2013, 60, 217-224. [CrossRef]

28. Liang, X.; Yu, T.; Guo, L. Understanding Stakeholders' Influence on Project Success with a New SNA Method: A Case Study of the Green Retrofit in China. Sustainability 2017, 9, 1927. [CrossRef]

29. Lund, A.J.; Eskerod, P. Stakeholder analysis in projects: Challenges in using current guidelines in the real-world Stakeholder Analysis. Department of Environmental and Business Economics. Int. J. Proj. Manag. 2009, 27, 335-343.

30. McElroy, A.M.B. Gower Handbook of Project Management; Gower Publishing Limited Hampshire: Hampshire, UK, 2000.

31. Wallbaum, H. Harnessing stakeholder motivation: Towards a Swiss sustainable building sector. Build. Res. Inf. 2011, 39, 504-517.

32. Dooley, K.; Sormunen, P. Capturing the Stakeholder Values of a Construction Project. In Proceedings of the SB10 Finland Sustainable Community-BuildingSMART Conference, Espoo, Finland, 22-24 September 2014; Volume 10.

33. Bertoldi, P.; Boza-Kiss, B. Analysis of barriers and drivers for the development of the $\{$ ESCO $\}$ markets in Europe. Energy Policy 2017, 107, 345-355. [CrossRef] 
34. Haavik, E.; Aabrekk, T.; Prendergast, S.E. Business Opportunities in Sustainable Housing. A Marketing Guide Based on Experiences from 10 Countries. 2007. Available online: https:/ /www.ntnu.no/c/document_library/get_file?uuid=315ba3e8-839 e-4b37-904b-5b5d64181faf\&groupId=10361 (accessed on 14 April 2021).

35. John, M.; Niall, D.; Rosemarie, M. Energy efficiency in commercial buildings: Capturing added-value of retrofit. J. Prop. Invest. Financ. 2014, 32, 396-414.

36. Vandevyvere, H.; Van De Vyver, I.; Van Den Broeck, P. Integrated Decision Support Tool for Retrofit and Renewal towards Sustainable Districts-Final Report; European Commission: Brussels, Belgium, 2017.

37. Palonen, J. SQUARE-A System for Quality Assurance when Retrofitting Existing Buildings to Energy Efficient Buildings; SQUARE: Borås, Sweden, 2010.

38. Britnell, J.; Dixon, T. Retrofitting in the private residential and commercial property sectors-survey findings. Work Package 2011, 2, 2020-2050.

39. Häkkinen, T.; Lützkendorf, T.; Balouktsi, M.; Immendörfer, A.; Nibel, S.; Bosdevigie, B.; Mäkeläinen, T. Sustainability and Performance Assessment and Benchmarking of Buildings-SuPerBuildings Final Report; Vtt: Espoo, Finland, 2012; pp. 1-23.

40. Bointner, R.; Kranzl, L.; Toleikyte, A. Zebra 2020-Nearly Zero-Energy Building Strategy 2020 Deliverable D2 1: Definition of Nearly Zero-Energy Buildings as Used for Market Tracking, 2016, pp.1-18. Available online: https://bpie.eu/wp-content/ uploads/2016/12/ZEBRA2020_Strategies-for-nZEB_07_LQ-double-pages.pdf (accessed on 14 May 2021).

41. Koerber, A.; McMichael, L. Qualitative Sampling Methods: A Primer for Technical Communicators. J. Bus. Tech. Commun. 2008, 22, 454-473. [CrossRef]

42. Simsek, Y.; Santika, W.G.; Anisuzzaman, M.; Urmee, T.; Bahri, P.A.; Escobar, R. An analysis of additional energy requirement to meet the sustainable development goals. J. Clean. Prod. 2020, 272, 122646. [CrossRef]

43. Dahal, K.; Niemelä, J. Initiatives towards carbon neutrality in the Helsinki metropolitan area. Climate 2016, 4, 36. [CrossRef]

44. Dahal, K.; Niemelä, J. Cities' Greenhouse Gas Accounting Methods: A Study of Helsinki, Stockholm, and Copenhagen. Climate 2017, 5, 31. [CrossRef]

45. Chastas, P.; Theodosiou, T.; Bikas, D.; Kontoleon, K. Embodied Energy and Nearly Zero Energy Buildings: A Review in Residential Buildings. Procedia Environ. Sci. 2017, 38, 554-561. [CrossRef]

46. Sartori, I.; Hestnes, A.G. Energy use in the life cycle of conventional and low-energy buildings: A review article. Energy Build. 2007, 39, 249-257. [CrossRef]

47. Dahal, K.; Juhola, S.; Niemelä, J. The role of renewable energy policies for carbon neutrality in Helsinki Metropolitan area. Sustain Cities Soc. 2018, 40, 222-232. [CrossRef]

48. Robati, M.; Oldfield, P.; Nezhad, A.A.; Carmichael, D.G.; Kuru, A. Carbon value engineering: A framework for integrating embodied carbon and cost reduction strategies in building design. Build. Environ. 2021, 192, 107620. [CrossRef]

49. Takano, A.; Hughes, M.; Winter, S. A multidisciplinary approach to sustainable building material selection: A case study in a Finnish context. Build. Environ. 2014, 82, 526-535. [CrossRef]

50. Omer, M.A.B.; Noguchi, T. A conceptual framework for understanding the contribution of building materials in the achievement of Sustainable Development Goals (SDGs). Sustain. Cities Soc. 2020, 52, 101869. [CrossRef]

51. Alam, S.; Moula, M.E.; Lahdelma, R. Social acceptability of using low carbon building: A survey exploration. Int. J. Sustain. Energy 2020, 39, 951-963. [CrossRef]

52. Vares, S.; Häkkinen, T.; Ketomäki, J.; Shemeikka, J.; Jung, N. Impact of renewable energy technologies on the embodied and operational GHG emissions of a nearly zero energy building. J. Build. Eng. 2019, 22, 439-450. [CrossRef]

53. Karhunmaa, K. Attaining carbon neutrality in Finnish parliamentary and city council debates. Futures 2019, 109, 170-180. [CrossRef]

54. Khalil, N.; Husin, H.N.; Mahat, N.; Nasir, N. Sustainable environment: Issues and solutions from the perspective of facility managers. Procedia Eng. 2011, 20, 458-465. [CrossRef]

55. Sonia, G.; Michael, P. Determining the role of innovation management in facilities management. Facilities 2007, 25, 48-60.

56. Deng, S.; Wang, R.Z.; Dai, Y.J. How to evaluate performance of net zero energy building-A literature research. Energy 2014, 71, 1-16. [CrossRef] 